\title{
The immunopathology of thymic GVHD
}

\author{
Werner Krenger • Georg A. Holländer
}

Received: 5 August 2008 / Accepted: 30 September 2008 / Published online: 31 October 2008

(C) Springer-Verlag 2008

\begin{abstract}
The clinical success of allogeneic hematopoietic stem cell transplantation (HSCT) depends on the appropriate reconstitution of the host's immune system. While recovery of T-cell immunity may occur in transplant recipients via both thymus-dependent and thymus-independent pathways, the regeneration of a population of phenotypically naive $\mathrm{T}$ cells with a broad receptor repertoire relies entirely on the de novo generation of T-cells in the thymus. Preclinical models and clinical studies of allogeneic HSCT have identified the thymus as a target of graft-versus-host disease (GVHD), thus limiting T-cell regeneration. The present review focuses on recent insight into how GVHD affects thymic structure and function and how this knowledge may aid in the design of new strategies to improve T-cell reconstitution following allogeneic HSCT.
\end{abstract}

Keywords Hematopoietic stem cell transplantation . Graft-vs.-host disease · T-cell reconstitution · Thymus . Thymic epithelial cells

\footnotetext{
W. Krenger · G. A. Holländer

Department of Biomedicine, University of Basel,

Basel 4005, Switzerland

W. Krenger · G. A. Holländer

Basel University Children's Hospital (UKBB),

Basel 4005, Switzerland

W. Krenger $(\triangle) \cdot$ G. A. Holländer $(\triangle)$

Laboratory of Pediatric Immunology, Department of Biomedicine,

University of Basel,

Mattenstrasse 28,

4058 Basel, Switzerland

e-mail: werner.krenger@unibas.ch

e-mail: georg-a.hollaender@unibas.ch
}

\section{Introduction}

Present cytoreductive conditioning regimens in the context of hematopoietic stem cell transplantation (HSCT) cause defects within the immune system. Either transient or protracted in nature, the post-transplant immune deficiency can last for more than a year and is invariably associated with an increased risk for opportunistic infections, inflammation, reactivation of latent infections, disease relapse, and the development of secondary malignancies. Hence, rebuilding innate and adaptive immunity is a critical issue for patients receiving HSCT, as is discussed elsewhere in this issue of Springer seminars in Immunopathology.

The process of post-transplant immune reconstitution depends on two mutually non-exclusive pathways, including (1) the clonal expansion of donor graft- and residual host-derived mature hematopoietic cells in peripheral tissues of the host and (2) the de novo generation of cells of the lymphoid and myeloid lineages from the transferred hematopoietic stem cells (HSC). Whereas the natural immune system (i.e. epithelial barriers, granulocytic cells, phagocytes, and natural killer cells) typically recovers within a few weeks post-transplant, the renewal of the adaptive immune system is subject to a complex and slow process which usually takes months (for B cells) to years (for $\mathrm{T}$ cells) to be accomplished, even under favorable conditions (see article by J. Storek in this issue)

Multiple parameters determine the speed of T-cell reconstitution following HSCT: host factors such as age, gender, type of conditioning and underlying pathology; genetic differences between donor and host; stem cell source; post-HSCT events such as acute and chronic graftvs.-host disease (GVHD) and their respective therapies; relapse of malignancy; and infection by various microbial 
pathogens contribute to the kinetics of peripheral T-cell recovery [1-15]. Early T-cell immunity present in transplant recipients may be provided by residual, conditioning resistant host $\mathrm{T}$ cells or by an inadvertent or intentional therapeutic transfer of mature $\mathrm{T}$ cells of donor origin [7, 16-19]. As the oligoclonal expansion of these cell populations confers, however, only a limited degree of immune competence, new $\mathrm{T}$ cells need to be generated which, in turn, necessitates a functionally intact thymus.

The thymic generation of new $T$ cells assures the long-term regeneration of a broad T-cell antigen receptor (TCR) repertoire able to recognize a wide range of antigens. The cellular and molecular mechanisms operational in the maintenance of thymic function in healthy, diseased, or aged individuals have therefore received considerable attention over the last few years. The collected insights reveal that thymus-dependent T-cell reconstitution may be limited by age-related thymic changes and by transplant-related toxicities stemming from conditioning or graft-vs.-host disease.This review discusses recent insight into how acute and chronic GVHD affect thymic function and how a detailed understanding of the molecular and cellular mechanisms of these immunopathologies may lead to novel therapeutic approaches that boost thymic function after HSCT.

\section{Normal postnatal thymic T-cell maturation and export}

The thymus is the primary site of $\mathrm{T}$ lymphopoiesis during fetal and early postnatal life (for extended reviews see references [20-24]). Organized into the subcapsular region, the cortex, the cortical-medullary junction, and the medulla, the cellular architecture of the thymus is highly conserved between different vertebrate species and may hence reflect a functional importance for this partition. As the thymus does not contain hematopoietic precursor cells with a capacity for unlimited self-renewal, T-cell progenitors are continuously recruited to this site from the bone marrow via the blood (see article by D.A.Zlotoff in this issue). These precursors enter the thymus at the cortico-medullary junction and, once positioned within the thymic microenvironment, develop there in an ordered maturational sequence to phenotypically and functionally mature $\mathrm{T}$ cells [25]. Thymopoiesis relies upon different signals which are provided by a functionally competent stromal network. This scaffold contains thymic epithelial cells (TEC), bone-marrow-derived cells and mesenchymal cells [26, 27] (see below). Positive and negative selection effected by cortical (c) and medullary (m) TECs and dendritic cells (DCs) shape a repertoire of TCRs that respond to a seemingly unlimited array of foreign ('Non-Self') antigens while remaining unresponsive to the host's own tissues ('Self’).
The thymic stromal compartment

All non-lymphoid cells of the thymus are commonly referred to as stroma although their functional importance would identify them more appropriately as thymus parenchyma. TECs constitute the major component of this threedimensional scaffold. Contrary to all epithelia in other tissues, the vast majority of TECs lack the typical cell polarity of epithelia and are not placed on a basal membrane but are arranged in a three-dimensional orientation so that their dendrite-like processes form cell-cell contacts which create a continuous network [23, 26, 27]. In addition to TECs, the thymic stromal compartment also contains mesenchymal cells such as reticular fibroblasts and hematopoietic cells including DCs and macrophages. Together, these cells form a complex microenvironment that is not only competent to attract blood-borne precursors but that is also uniquely capable to induce commitment to a T-cell lineage and to efficiently support the survival, expansion, differentiation, and selection of thymocytes so that functionally and phenotypically mature $\mathrm{T}$ cells are generated [20, 28].

TECs derive exclusively from the endodermal lining of the third pouch in mice and of the third and fourth pouch in humans [27, 29]. Recent experimental evidence has unequivocally established in the fetal mouse that a single intrathymic epithelial cell can develop into the different TEC subpopulations required for the establishment of a functional thymic microenvironment $[30,31]$. Whether such a thymic epithelial stem cell exists in the postnatal thymus also under physiological conditions has not yet been unequivocally proven. Once a thymus primordium is formed, the TEC precursors differentiate into discrete cortical and medullary epithelial subsets, a step that is initially independent of signals from immigrating hematopoietic cells [32]. Embryonal and postnatal TEC proliferation and differentiation depend on signals mediated by epithelial cell mitogens, such as Fgf7 (fibroblast growth factor-7; a.k.a. keratinocyte growth factor) [33-36] (see below). The continued development and subsequent maintenance of the separate cortical and medullary compartments require reciprocal interactions between developing thymocytes and TECs, a process coined thymic crosstalk [37]. Although thymic stroma cells expand rapidly during mouse fetal development and continue to do so until week 4 after birth, the proportion of these cells compared to total thymic cellularity decreases progressively to a ratio of one stromal cell to on average of 440 thymocytes at 4 weeks of age and to approximately 320 thymocytes after puberty. These extensive changes are paralleled by a continuous turnover of thymic stromal cells resulting in a complete replacement of the TEC compartment every 10 to 14 days $[38,39]$. Even though the number of human TECs still expands in the first year after birth, both size and function of 
the thymus gradually diminish with and following the second year of life [40-42].

The population of thymic epithelia is phenotypically and functionally heterogeneous not only between the structurally distinct cortical and medullary compartments but also within these domains. While a detailed analysis of TEC numbers and phenotype has not yet been performed for the human thymus, quantitative data and a description of lineage- and development-specific cell markers is available for mice $[38,43]$. For example, the expression of the cytokeratins-5 (K5) and K18 in conjunction with the detection of a UEA-1 binding lectin and at times other not yet well characterized cell surface glycoproteins allow to identify cTECs and mTECs as well as subpopulations within these particular groups of thymic epithelia (murine major cortical TECs display a $\mathrm{K} 18^{+} \mathrm{K} 5^{-} \mathrm{UEA}^{-1}{ }^{-} \mathrm{MTS} 10^{-}$ phenotype, the minor cortical TECs are $\mathrm{K} 18^{+} \mathrm{K} 5^{+}$UEA$1^{-}$MTS $10^{-}$, major medullary TECs are characterized as $\mathrm{K}^{+} \mathrm{MTS}^{+} 0^{+}$and minor medullary epithelial cells stain K $18^{+}$UEA- $\left.{ }^{+}[20,35,44]\right)$. The microenvironment built by cTECs supports the initial (i.e. most immature) developmental stages in intrathymic T-cell development and enforces the probing of the TCR affinity required for positive selection. In contrast, mTECs together with DCs enriched at the cortical-medullary junction but also dispersed throughout the medulla are responsible for negative thymic selection.

By virtue of specialized TEC subpopulations, the thymus is able to generate tolerance not only to ubiquitous selfantigens but also to antigens that are typically expressed in a tissue-restricted fashion. Whereas the need for negative selection of TCR specificities recognizing the most common if not all self-antigens was appreciated as a necessity to effect meaningful central T-cell tolerance, the molecular control of this vital process remained for a long time largely enigmatic. It is now well established that mTECs hold the unique capacity to ectopically express and present a vast array of different organ-specific antigens which provides a 'molecular mirror of peripheral Self' $[45,46]$. Hence, this promiscuous expression permits the negative selection of TCRs that recognize with high affinity tissue-restricted antigens (TRA) when complexed to self-major histocompatibility complex (MHC) molecules [45, 47]. Some of these TRAs are in their expression under the control of the transcription factor autoimmune regulator (Aire) [48]. Lack of Aire expression is the genetic cause of the autoimmune polyendocrinopathy-candidiasis-ectodermal dystrophy (APS-1) syndrome, an autosomal recessive disorder marked by the persistence of autoreactive $\mathrm{T}$ cells in the periphery [49]. Direct evidence for a decisive role of Aire in negative thymic selection has been provided by experiments with TCR transgenic mice where expression of the cognate antigen is under the control of Aire [50, 51]. Under these experimental conditions, a correlation was established between the level of Aire expression, the number of TRAspecific transcripts controlled by Aire and the extent of negative selection affecting T cells with a TCR specific for a given TRA [51]. The precise regulation of Aire expression is thus indispensable to shape correctly a TCR repertoire that is devoid of high affinity specificities directed at self-antigens. Since the process of clonal deletion of self-reactive $\mathrm{T}$ cells is not entirely efficient, additional mechanisms are fortunately in place that secure the induction of self-tolerance. For example, the thymus generates a population of regulatory $\mathrm{T}$ cells $\left(\mathrm{T}_{\text {reg }}\right)$ that is at present characterized by their signature $\mathrm{CD} 4{ }^{+} \mathrm{CD} 25^{+}$ phenotype and the expression of the transcription factor Foxp3. The function of $\mathrm{T}_{\text {reg }}$ is to control those self-reactive $\mathrm{T}$ cells that have wrongly escaped negative thymic selection and settled in peripheral tissues [52-54]. For their formation, $\mathrm{T}_{\text {reg }}$ require a TCR that binds with a high enough affinity to its cognate ligand on TECs and thymic DCs. It remains, however, unknown how this level of TCR affinity shuns the typical fate following a high affinity interaction with a MHC/peptide complex, an event leading in conventional $\mathrm{T}$ cells to negative selection. The relative contribution of TEC and DC in fostering this generation of $\mathrm{T}_{\text {reg }}$ is still not settled and awaits to be resolved $[55,56]$.

\section{Thymic export and its detection}

$\mathrm{T}$ cells are continuously exported to peripheral lymphoid tissues by mechanisms that are only incompletely understood at present but that are independent of a feedback mechanism sensing the number of peripheral T cells [56]. Informative cell surface markers that accurately identify recent thymic emigrants (RTE) among mature peripheral T cells are lacking for both mice and humans. Consequently, it has been difficult in practice to precisely determine in vivo the thymic export of new $\mathrm{T}$ cells during steady-state and under conditions of disease. The expression of CD45 splice variants is commonly, but not always correctly [57], used as a marker to enumerate naïve (i.e. CD45RA ${ }^{+}$) $\mathrm{T}$ cells. Detection of other cell surface markers such as CD62L, $\mathrm{CD} 27, \mathrm{CD} 31$, or CD103 ( $\alpha \mathrm{E} \beta 7$ integrin) may also aid in the identification of human naive $\mathrm{T}$ cells but again, their cell surface expression is not exclusive for RTE [2, 9, 58-60]. Thymic T-cell output in humans and in mice has been quantified in more recent studies by measuring T-cell receptor rearrangement excision circles (TRECs) [2, 3, 41, 61-74]. These extrachromosomal, non-replicating DNA circles are a byproduct of the rearrangement of the TCR $\alpha /$ $\delta$ locus (TCRAD) and are exclusively generated during the $\mathrm{CD}^{+} \mathrm{CD}^{+}$stage of intrathymic T-cell development. Two sequential rearrangement steps during human $\mathrm{TCR} \alpha \beta^{+}$ thymocyte development result in the formation of signal 
joints (sj) TRECs and coding joints (cj) TRECs. Since these steps are identical in $\sim 70 \%$ of all cells, a PCR-based analysis of TRECs is feasible and practical [75, 76]. TRECs are measured from DNA extracted from a defined population of typically $10^{5}-10^{6}$ blood mononuclear cells or sorted $\mathrm{CD}^{+}$or $\mathrm{CD}^{+} \mathrm{T}$ cells. The calculated number of TRECs per cell is then referred to as TREC content. In addition to the measurement of sjTRECs derived from the TCRAD locus, measurements of TRECs from the V(D)J rearrangements of the $\beta$-chain locus have now also been successfully employed to determine RTE [77].

New T cells are generated in the thymus throughout life but the size of this organ and in consequence the number of RTE changes as a function of age [11]. Thymic T-cell output is in humans particularly high during the fetal and perinatal period, but thymopoietic function and consequently the exit of naïve $T$ cells decrease swiftly following the first year of life and are again further diminished shortly before the onset of puberty. Although structural and functional involution are characteristic hallmarks of the aging thymus and are already present at a relatively young age, phenotypically naïve $\mathrm{TREC}^{+}$cells can still be detected in the peripheral blood of octogenarians and even older individuals $[19,78,79]$. Physiological thymic involution affects both the lymphoid and the stromal compartments of the thymus, and is paralleled by an increase in perivascular space and adipose tissue $[38,80]$.

\section{Pathways of post-transplant T-cell regeneration}

Preclinical and clinical studies have interrogated the respective roles of peripheral expansion and thymusdependent T-cell maturation in the process of T-cell regeneration following conditioning-dependent lymphodepletion and HSCT. Results from these studies $[1,2,5-9,11$, $15,19,60,67,81,82]$, indicate that T-cell reconstitution occurs via both thymus-independent and thymus-dependent pathways but that their individual kinetics are variable owing to (1) genetic differences between donor and recipient, (2) the age of the recipient, (3) the use of T-cell depleted (TCD) vs. unmanipulated grafts, (4) the infusion of bone marrow vs. mobilized peripheral blood stem cells, (5) myeloablative vs. non-myeloablative pre-treatment, and (6) the absence vs. presence of transplant-related complications such as GVHD.

\section{Thymic-dependent T-cell regeneration in humans}

During life, peripheral $\mathrm{T}$ cellularity is primarily regulated by homeostatic expansion $[19,83]$. Under physiological steady-state conditions, thymic T-cell export clearly plays only a minor role in maintaining regular $\mathrm{T}$-cell numbers in peripheral lymphoid tissues, even in the face of the several million naive $\mathrm{T}$ cells that are daily exported from a normal thymus at young age [84]. Under conditions of severe lymphodepletion, the generation of new TCR specificities is, however, critical to regenerate a peripheral T-cell compartment that is able to provide sustained adaptive immunity. Indeed, the degree of posttransplant TCR repertoire contraction is correlated to host immune incompetence and hence determines clinical outcome [85]. Although there is some evidence for extrathymic differentiation at various anatomical sites [86], the most efficient maturation of new T cells occurs in the thymus. Hence it is the extent of thymic function as influenced by senescence, cytoreductive treatment or transplant-related toxicities (TRT) that will determine the efficiency by which the peripheral T-cell compartment is reconstituted following lymphodepletion $[16,19,62,68$, 87-90].

Several weeks are required before mature thymic $\mathrm{T}$ cells arise from bone marrow-resident precursors [84, 91]. It is therefore not surprising that a substantial restoration of the T-cell compartment with naïve cells constitutes a very timeconsuming process that requires even under favorable conditions at least 1-2 years [82]. Independent of specific transplantation protocols employed, the recovery of the peripheral T-cell compartment is typically marked by the emergence of $\mathrm{CD}^{2} 5 \mathrm{RA}^{+}, \mathrm{CD} 62 \mathrm{~L}^{+} \mathrm{T}$ cells that harbor TRECs (i.e. bona fide RTEs $[2,3,6,9,13,15,16,18$, $19,62,67,68,70,81,82,89,92-101])$. The quality of the renewing T-cell compartment is at present most precisely measured by functional T-cell assays such as the measurement of pathogen-specific T-cell proliferation and by the assessment of TCR diversity using either flow cytometric quantification of TCRV $\beta$ usage or PCR-based spectratyping of the complementarity determining region 3 (CDR3) of the TCR- $\beta$ chain $[9,62,82,85,96-98,102-107]$.

Thymic selection: the allogeneic HSCT concern

TCR selection depends on the exposure of developing lymphoid precursors to self-peptide/MHC complexes on different thymic stromal cell types. Positive thymic selection occurs in the cortex where TCRs are selected that display an intermediate affinity for the combination of self-peptides and self-MHC complexes expressed by cTECs. Surviving TCR specificities are then monitored in the medulla for reactivity to self-peptides presented by either mTECs or by bone marrow-derived DCs in a process termed negative selection. Under non-transplant conditions, the MHC haplotype expressed by hematopoietic and epithelial stromal cells is identical and this constellation assures that the MHC molecules on which positive and negative selection occurs are the same as those used for foreign antigen presentation by 
blood-borne, professional antigen presenting cells (APC) resident in all peripheral tissues. This physiological situation is contrasted by conditions that arise in HSCT recipients. Because of their radiation-resistance and non-hematopoietic origin, TECs remain of host origin. In contrast, the thymic stromal cells of hematopoietic origin (DCs, macrophages and other cells) are ablated by radio/chemotherapy and hence relatively quickly replaced by donor-type cells following HSCT. In autologous HSCT or under conditions of complete MHC match between donor and host, the HLA molecules presented on thymic stromal cells remain identical for positive and negative thymic selection. In HLA-mismatched HSCT, radioresistant TECs will express the recipients' haplotype but the bone marrow-derived cells will be of donor origin and hence of a different haplotype. This variance in $\mathrm{MHC}$ restriction is thought to influence thymic T-cell repertoire selection and, in consequence, that of the peripheral T-cell pool. Indeed, clinical data suggest that TCR repertoire diversity is only mildly perturbed in recipients of unmanipulated bone marrow from HLA-identical, related donors whereas a skewed TCR repertoire (at least for the first years after transplantation) is noted in recipients of unrelated or HLA-mismatched, related donors, particularly under conditions where the bone marrow inoculum was depleted of T cells [97, 108, 109].

Several specific aspects related to the difficulty of predicting TCR repertoire selection and T-cell function in HLA-disparate transplant recipients (be it in the absence or presence of GVHD) require a closer investigation. To address these issues in the most extreme situation, we will focus here on the haploidentical HSCT setting. Although naïve $\mathrm{T}$ cells emerge after intense conditioning and haploidentical HSCT [110-112], little is known with reference to the TCR repertoire complexity generated, the MHC restriction and the functional competence of the emerging $\mathrm{T}$ cells. Given the disparity in HLA expression between the epithelial cells required for positive selection and the hematopoietic cells involved in negative thymic selection, a distortion of the regenerating TCR repertoire is to be expected. Indeed, autoreactive $\mathrm{T}$ cells can be recovered at a relatively high frequency in mice that express a particular MHC class II molecule only on cTECs, but not on DCs or mTECs [113, 114]. Related to this situation are observations that an unopposed positive selection due to the absence of MHC class II expression on mouse thymic DCs generates a T-cell repertoire which causes either autoimmune colitis [115], or autologous GVHD in normal syngeneic mice [116], or chronic GVHD in MHCdisparate recipient mice [117]. These experimental findings underscore the necessity for correct negative thymic selection and suggest that an only positively selected TCR repertoire includes autoreactive TCR specificities with the evident potential to cause autoimmune pathology. Hence, a difference in the set of MHC-restricting elements between positively selecting cTECs and negatively selecting DCs may allow the survival and thymic export of autoreactive $\mathrm{T}$ cells. In this context it is however interesting to note that an effective reconstitution of TCR diversity and function appears to be possible in disease-free patients following the engraftment of TCD haploidentical bone marrow cells [118126]. These individuals produce within 2 to 3 years a repertoire of TREC-positive $\mathrm{T}$ cells that displays a normal $\mathrm{V} \beta$ complexity. While further studies with larger patient cohorts will be needed to confirm independently these results, the data so far suggests that thymic positive and negative selection can remain undisturbed after engraftment of HLA-mismatched HSC. Specifically, these results imply that the emerging T-cell compartment exhibits a TCR repertoire comparable to that of recipients of TCD and HLA-matched grafts [127]. As encouraging as these results appear, they are difficult to interpret and the impact of correct negative thymic selection for the generation of these cells will need to be investigated in more detail. Nonetheless, the principle still stands that MHC-restricted T-cell selection is most efficient and robust under conditions where stromal cells and bone marrow-derived cells share an identical MHC $[128,129]$.

Evidence exists both from experimental animal models and from transplanted immunodeficient patients that cells other than TECs can execute positive thymic selection. For example, the intrathymic injection of fibroblasts or medullary epithelial-like cells select $\mathrm{T}$ cells that are restricted to the MHC present on the transferred cells [130-132]. Reconstitution of athymic mice with allogeneic thymic stromal cells results in the formation of mature, functionally competent $\mathrm{T}$ effector cells that are restricted to thymic donor but not recipient MHC molecules [129]. Alternatively, developing thymocytes can be positively selected by hematopoietic cells and the transgenic expression of MHC class II molecules on immature thymocytes of the mouse is sufficient to select functionally competent $\mathrm{CD}^{+} \mathrm{T}$ cells with a mature phenotype and a polyclonal TCR repertoire [133]. While some of this experimental evidence argues that a thymus stromal defect can be efficiently corrected by allo- (and possibly xenogeneic) thymic grafts, it is the second set of data that would claim that thymocyte-thymocyte interactions suffice for positive selection of $\mathrm{CD}^{+} \mathrm{T}$ cells (at least in the mouse, where MHC class II molecules are not normally expressed by thymocytes and $\mathrm{T}$ cells). Taken together, these experimental models may have uncovered a previously unappreciated, independent pathway of positive thymocyte selection that may play a physiological role in species such as man where thymocytes physiologically express MHC class II molecules. Strikingly, the selection, MHCdependent amplification and survival of mature $\mathrm{T}$ cells 
educated either on TEC or non-TEC MHC appear to be equivalent, at least under the experimental conditions tested [134].

Support for a concept that the thymus holds the capacity to generate a TCR repertoire which is not restricted to the MHC haplotype expressed by TECs also comes from patients with a complete DiGeorge anomaly that have been transplanted with a postnatal, HLA-non-matched thymus graft to achieve reconstitution of their T-cell compartment $[135,136]$. In these patients, mature host-type $\mathrm{T}$ cells are detected as early as 6 months after transplantation. These cells respond to nominal, T-cell-dependent antigens which indicates that they are (if not exclusively, so at least sufficiently) restricted to host-type MHC molecules [137, 137]. Although not yet formally demonstrated in transplanted patients with the complete DiGeorge anomaly, indirect evidence would suggest that positive thymic selection is mediated in these patients by bone marrowderived cells. However, it needs to be stressed that neither vigor nor efficiency of this "non-canonical" selection process has been established. It is therefore important to address in more detail the MHC restriction bestowed on $\mathrm{T}$ cells of athymic individuals grafted with non-HLA matched thymic stroma and to test the functionality of their peripheral $\mathrm{T}$ cells at both a molecular and expanded functional level.

While it is tempting to speculate on the main function of the thymic epithelial cells to establish a microenvironment that promotes TCR expression in an MHC-unspecific fashion whereas the organ's hematopoietic components control the TCR repertoire through an MHC-dependent mechanism, several important issues related to selection and hence central tolerance induction remain unanswered. For example, the role of tissue restricted self-antigens expressed by mTECs is not considered in this alternative model. However, such antigens and the mechanism by which they are expressed may be critical to prevent autoimmunity. In view of this competence for promiscuous gene expression, the epithelial thymic microenvironment is, indeed, mostly unique and cannot be replaced by hematopoietic cells $[45,48]$.

\section{GVHD as a major limitation of thymus-dependent T-cell regeneration}

Qualitative and quantitative restrictions related to the thymus-dependent T-cell development have been causally linked to a functionally incapacitated peripheral T-cell compartment. Among the obstacles that influence thymusdependent T-cell regeneration, the age of the transplant recipient and the treatment-related toxicities confound thymic function the most.
Human thymus function in the context of acute GVHD

GVHD is a complication of allogeneic HSCT which can occur in an acute and a chronic course, with each form highlighted by different clinical features, and distinct kinetics in their presentation due to differences in their respective pathomechanisms [10, 138-143]. Occurring at considerably high frequencies in sibling donor recipients and unrelated donor (URD) recipients, incidence and severity of acute GVHD depend on several factors, including histoincompatibility, age, graft composition, host environment, GVHD prophylaxis method, and the type of host conditioning. Acute GVHD manifests in a limited set of tissues, including the liver, skin, gastrointestinal tract, and lung. Although clinical practice has so far focused mainly on the involvement of these "typical" organ targets, it is now broadly accepted that the host's lymphohematopoietic system serves as primary target of acute GVHD [144].

The presence of acute GVHD in allogeneic HSCT recipients is a major predictor for an increased probability to be diagnosed with an opportunistic infection $[3,10,69,97$, $127,142,145-147]$. As the pool of potential HSC donors increasingly includes genetically disparate, unrelated individuals [148], both frequency and severity of GVHD are currently rising among transplant recipients. Consequently, clinically relevant immunodeficiency will likely increase in these patients. A detailed understanding of the GVHDrelated pathomechanisms that compromise the host's immune competence will thus be decisive to improve clinical outcome.

GVHD severity is inversely correlated to the capacity to recover T-cell immune competence [3, 69, 106, 149]. Both the immunosuppressive measures taken for GVHD prophylaxis/treatment [6] and the immune-mediated effects of acute GVHD per se are detrimental and account for the observed T-cell deficiency [70]. As early as 30 years ago, clinical observations had identified the thymus as a target of GVHD since morphological changes affecting both the lymphoid and epithelial components of the thymus could be observed in patients following allogeneic HSCT [150-154]. Typical histological features of GVHD-induced thymic dysplasia include the depletion of cortical and medullary thymocytes, changes in the number and composition of the different thymic epithelial cell subpopulations, disappearance of the corticomedullary demarcation, phagocytosis of cellular debris, and the elimination of Hassall's bodies [150, 155, 156]. The loss of the regular tissue architecture is paralleled by deficits in thymopoiesis as confirmed by a distorted TCR repertoire and lower TREC levels when compared to healthy controls [3, 68, 69, 157]. Although the lower TREC levels in recipients of HSCT have been interpreted as the consequence of a decreased thymic output due to GVHD, 
an alternative explanation also needs to be considered. Indeed, some studies have failed to demonstrate an association between TREC levels and the presence of acute or chronic GVHD [66, 67] because TREC content is not only affected by thymic output but also by the proliferative kinetic of both TREC ${ }^{+}$and TREC ${ }^{-}$cells $[70,73,74]$. Thus, assessments of peripheral events such as cellular expansion [158] and cell removal by death will need to be combined with TREC analysis in order to draw informative conclusions with regard to changes in thymic export.

Pathomechanisms of thymic insufficiency: insights from preclinical GVHD models

Preclinical allogeneic HSCT models have provided informative insight for a better understanding of GVHD. The immunopathophysiology of acute GVHD may be divided into three distinct but interrelated phases: (1) tissue damage attributable to previous therapy and conditioning regimens, (2) donor T-cell activation following interaction with professional host-derived APC in a process termed 'GVH reaction', and (3) injury of a limited number of target tissues by multiple soluble and cellular effectors $[10,138$, 141-143, 159-166]. The secretion of disease-promoting cytokines, especially interferon (IFN)- $\gamma$, occurs in all three phases $[159,160,167-174]$ and as a single factor plays hence a critical role in acute GVHD.

Experimentally induced thymic dysplasia mimics the features typically observed in human GVHD, including the loss of cortical cellularity, the lack of a cortex/medulla demarcation, the absence of a regular composition and organization of the different TEC subpopulations, the loss of regular TCR repertoire selection, and the diminished number of TREC $^{+}$cells $[3,4,18,44,69,151-154,158$, 173-184]. Whereas the effects of chemo- and radiotherapy on thymic cell composition and architecture are well known [185-187], the immunological mechanisms underlying thymic injury have only recently begun to be investigated. To this end, the transfer of parental $\mathrm{T}$ cells into haploidentical $\mathrm{F}_{1}$-progeny provides a specially adapted preclinical transplantation model as it circumvents the need for irradiation [188] and hence provides an experimental system to investigate the direct impact of an anti-host immune response on thymic structure and function. Under these experimental conditions, thymic hypocellularity is primarily the consequence of a depletion of the most populous double-positive (DP. i.e. $\mathrm{CD} 4^{+} \mathrm{CD} 8^{+}$) thymocyte subset. Two independent mechanisms account for this finding. The first pathway encompasses the failure of resident CD3,CD4, CD8 triple-negative (TN) thymocytes to proliferate adequately. TN cells are further subdivided into four distinct subsets based on their surface expression of CD44 and CD25. Maturation within the TN compartment occurs in the sequence $\mathrm{CD} 25^{-} \mathrm{CD} 44^{+}$(stage $\left.\mathrm{I}\right) \rightarrow \mathrm{CD} 25^{+} \mathrm{CD} 44^{+}$ (stage $\mathrm{II}) \rightarrow \mathrm{CD} 25^{+} \mathrm{CD} 44^{-}$(stage $\left.\mathrm{III}\right) \rightarrow \mathrm{CD} 25^{-} \mathrm{CD} 44^{-}$ (stage IV) [189]. The progression of TN thymocytes to the DP cell stage is paralleled under physiological steadystate conditions by a 20- to 50-fold expansion in cell number [190]. The frequency of stage I TN cells is increased during acute GVHD in lieu of cells with a stage III TN phenotype [173]. This observation is in keeping with cell cycle analysis during acute GVHD demonstrating that viable TN cells of stages II, III and IV are severely inhibited in their in vivo proliferative capacity. This finding is of relevance for T-cell development because only TN thymocytes that have productively rearranged one of their TCR $\beta$ gene loci are allowed to progress to the DP stage. A lack of a strong clonal expansion therefore results in a failure to generate a sufficiently large number of DP thymocytes which leads to overt thymic atrophy [173]. The second pathway leading to DP depletion concerns the increased programmed cell death among DP thymocytes, an event further contributing to thymic lymphopenia. Systemic effects have first been taken into consideration to be the reason for cell death. For example, experimental and clinical observations indicate that high pharmacological doses of glucocorticoids induce rapid apoptosis among immature thymocytes [191]. A role of steroids in thymic hypoplasia would in turn be consistent with the fact that the hypothalamus-pituitary-adrenal axis is activated during acute GVHD [192-194]. Pharmacologically blocking the steroid receptor has, however, no influence on the frequency and absolute number of DP undergoing apoptosis during acute GVHD, excluding the possibility that a systemic, glucocorticoid-dependent mechanism accounts for the loss of DP thymocytes [184].

Alloimmune-mediated effects on the thymic lymphoid and stromal compartments must therefore be considered. Recent analyses have focused on the architecture and composition of the TEC subpopulations and revealed that TECs undergo programmed cell death following transfer of allogeneic T-cells into unconditioned, fully MHC-disparate recipients [174]. Mainly cortical TECs are depleted in the course of acute GVHD, identifying these particular stromal cells as potential targets of allorecognition. Cortical TEC reduction displays rapid kinetics since a substantial number of $\mathrm{K} 18^{+} \mathrm{TEC}$ has undergone programmed cell death as early as 2 weeks after acute GVHD induction. Apoptotic TEC are typically located in areas of elevated epithelial density and adjacent to dying thymocytes. This feature is not only apparent following fully MHC-mismatched HSCT but also in an experimental setting in which the developing thymocytes, but not TECs, are donor-matched and thus do not constitute targets of an alloresponse [174]. Such data clearly indicate that a disruption of the stromal compartment as a consequence of an antigen-specific immune 
response is responsible for the disturbance of regular T-cell development. This mechanism would be consistent with the fact that donor-derived MHC-disparate T cells invade into the recipients' thymus, an event which has long been recognized to represent a typical feature of acute GVHD $[152,173,174]$. This invasion occurs even in the absence of pretransplant conditioning. The infiltrating $\mathrm{T}$ cells are detectable as early as 4 days after transplantation and their number in situ moreover correlates directly with the extent by which host thymopoiesis is disturbed. Definitive evidence that TECs can serve as direct targets of an alloimmune response has been gained from experimental systems using reaggregate thymic epithelial grafts. When grafts from fetal $\mathrm{H}-2^{\text {bd }}$ mice are transplanted into athymic $\mathrm{H}-2^{\mathrm{b}}$ recipients, they can be recognized and destroyed by infused mature $\mathrm{H}-2^{\mathrm{b}} \mathrm{T}$ cells. Importantly, this TEC injury suffices to abrogate regular thymocyte $\left(\mathrm{H}-2^{\mathrm{b}}\right)$ maturation in the ectopic thymi. In vitro experiments using co-cultures of purified naive T cells and MHC-disparate TECs have further established a direct and causative link between donor T-cell activation by TEC alloantigens, leading to their secretion of IFN- $\gamma$. This causes in TECs the activation of the IFN- $\gamma-$ responsive signal transducer and activator of transcription (STAT)-1 molecule and caspase-mediated apoptosis of these cells [174]. Hence, in addition to serving as disease-relevant targets of a GVH reaction, TECs are also competent and sufficient to prime naïve allogeneic $\mathrm{T}$ cells in the absence of hematopoietic host-type APCs [147, 173, 174].

The view that TECs can cell-autonomously act as professional APC for naive allogeneic T-cells is in keeping with previous findings using a similar parent $\rightarrow F_{1}$ chimera model $[195,196]$. Here, subsets of high-affinity resting Tcells were shown to become activated in vivo to class I and II alloantigens presented selectively on non-bone marrowderived cells. The TEC's unique capacity to prime naïve Tcells and to be recognized as allogeneic targets during acute GVHD may, however, be best accounted for by their inherent competence to present antigens to naïve $\mathrm{T}$ cells when compared to other epithelial cells that are regularly targeted by $\mathrm{T}$ cells in the context of acute GVHD. For instance, the transplantation of epithelia from thymic tissue taken at an early stage of organogenesis when the anlage is still devoid of DCs [197], causes acute rejection of the graft following the direct recognition of TECs by the transferred allogeneic $\mathrm{T}$ cells [198]. Indeed, TECs (but not other epithelia) display a constitutive expression of MHC class I and II molecules whose cell surface density may even surpass that of DCs [199]. Moreover, TECs which are organized in a three-dimensional fashion with only few epithelial cell/cell contacts, provide thus a loose meshwork easily accessible for alloresponsive immune cells. Although the in vitro immunogenic potential of TECs is lower when compared to hematopoietic professional APC [174], the functional and phenotypic characteristics of the TECs may render these cells nonetheless competent to activate $\mathrm{T}$ cells in vivo. It remains to be firmly established whether naive allogeneic T-cells actually enter the thymus, or whether this capacity is restricted to T-cells already activated in the periphery. Currently available experimental data addressing similar questions in experimental settings unrelated to allogeneicity would support either conclusion [200-203]. The fact that TECs may act as intrathymic APCs to activate naïve donor T cells is also supported by evidence that acute GVHD can be exclusively restricted to the thymus [174]. However, thymus-restricted structural and functional changes are not easily monitored by diagnostic tools currently available, rendering the diagnosis of thymic GVHD rather difficult,

A detailed understanding of the primary target of thymic GVHD is required to design novel strategies that may prevent allorecognition by mature donor $\mathrm{T}$ cells. In fact, because TECs act as competent APCs it is unlikely that a vigorous depletion of host-derived hematopoietic APCs (as part of pretransplant conditioning) will suffice to prevent the activation of alloresponsive donor T cells and hence preclude the consequential injury to TECs. Indeed, the expression of alloantigens $\left(\mathrm{H}-2^{\mathrm{d}}\right)$ exclusively on host non-hematopoietic thymic stromal cells is sufficient to cause an accumulation of transferred alloreactive donor T-cells $\left(\mathrm{H}-2^{\mathrm{b}}\right)$. These thymus-infiltrating T-cells $\left(\mathrm{CD}^{+}>\mathrm{CD} 4^{+}\right)$display 2 weeks after infusion an activated phenotype (i.e. are $\mathrm{CD} 44^{\text {high }}$, $\mathrm{CD}^{2} \mathrm{~L}^{\text {low }}, \mathrm{CD}^{-} 9^{-}$) and secrete high concentrations of IFN- $\gamma$ either spontaneously or after restimulation in culture. Moreover, extensive changes characterized by an altered stromal architecture and aberrant host T-cell development can be observed under conditions where alloantigens are only present on non-hematopoietic stromal cells of the thymus [174]. Taken together, these data clearly establish that alloreactive donor $\mathrm{T}$ cells can also be primed in vivo by TECs and that consequent changes in the composition, organization and viability of thymic stromal cells severely disturbs thymocyte maturation. With TECs efficiently recognized by donor $\mathrm{T}$ cells, future therapeutic efforts may therefore want to focus on strategies how to prevent and/or repair epithelial damage (see below). If successful, such endeavors are also likely to confirm a link between subclinical GVHD that is exclusively restricted to the thymus and an increased susceptibility for infections observed in recipients of unrelated donor HSCT.

Thymic dysfunction as a link to autoimmunity and chronic GVHD?

Although the number of allogeneic HSCT recipients who have now survived for two to three decades is increasing, only few of these individuals have fully regained their premorbid state of immunological health. The pathogenesis for 
late complications of HSCT is multifactorial, with some of these disorders displaying clearly an autoimmune pathology [204]. Autoimmunity after HSCT has many hallmarks of chronic GVHD, the latter being a pleiomorphic syndrome with onset originally occurring between 3 and 24 months after allogeneic HSCT [205]. While not all HSCT recipients with autoimmune syndromes experience also symptoms of chronic GVHD, there is a strong association between the development of chronic GVHD and autoimmune disease in HSCT recipients [206]. Experimental studies have thus far proposed at least four distinct pathomechanisms to explain chronic GVHD [207] implicating (1) regulatory cytokines such as transforming growth factor- $\beta$ (TGF- $\beta$ ) [208], (2) autoreactive B cells [209], (3) the deficiency of $\mathrm{T}_{\text {reg }}[210]$, and (4) a failure in negative thymocyte selection to play a critical role.

Reliable evidence for a responsibility of the thymus in the pathogenic events leading to chronic GVHD has been gained from different mouse transplantation models. In one model, thymic injury in recipients $(\mathrm{C} 57 \mathrm{BL} / 6)$ is caused by the infusion of $\mathrm{MHC}$-mismatched donor $\mathrm{CD}^{+} \mathrm{T}$ cells (C3H.SW). As a result, TCR repertoire selection among recipient-type $\mathrm{CD}^{+} \mathrm{T}$ cells is severely altered by the damaged thymic microenvironment and now includes specificities that are reactive to self-antigens [211]. In addition, these $\mathrm{T}$ cells are the result of an aberrant thymic selection process as they induce all the hallmarks of chronic GVHD when adoptively transferred into secondary naïve, syngeneic $(\mathrm{C} 57 \mathrm{BL} / 6)$ recipients. In contrast, these same $\mathrm{T}$ cells elicit an acute form of GVHD when injected into allogeneic (C3H.SW) mice. Hence, thymic damage in the course of acute GVHD will select a repertoire of T cells that is in due course able to cause autoimmune manifestations reminiscent of chronic GVHD. In keeping with these observations are results from bone marrow chimeric mice in which negative thymic selection of $\mathrm{CD}^{+} \mathrm{T}$ cells by hematopoietic APC is impaired due to the absence of MHC class II expression on DC but not TECs [116, 117]. As a consequence, the selected repertoire of $\mathrm{T}$ cells contains overtly autoreactive cells that induce chronic GVHD in MHC-mismatched recipients (C57BL/6-MHC II ${ }^{--} \rightarrow \mathrm{C} 3 \mathrm{H}$. $\mathrm{SW}$ ) and an 'autoimmune GVHD'-like syndrome in matched (C57BL/6-MHC II ${ }^{-/} \rightarrow$ C57BL/6) chimeras. Importantly, acute GVHD not only affects negative T-cell selection in the thymus but also impairs development of $\mathrm{T}_{\text {reg }}$ [212] which can prevent chronic GVHD [209]. Taking these preclinical data together, acute GVHD causes thymic injury, harms the TCR repertoire selection and consequently changes GVHD from an acute to a chronic form. Although not all cases of human acute GVHD evolve into chronic GVHD, the former has nonetheless been recognized as a risk for the latter. It is therefore intriguing to speculate that the early post-transplant impairment of TEC function and hence TCR selection provide an etiological link between the alloreactivity of acute GVHD and aspects of autoimmunity typically seen in the course of chronic GVHD [147]. In this context, the loss of Aire ${ }^{+}$TECs may constitute a crucial mechanism by which central tolerance induction is disturbed since this particular subpopulation of TECs is both instrumental in negative selection of autoreactive TCRs and in the generation of natural $T_{\text {reg. }}$. Preliminary data from our laboratory certainly indicate a dysregulation of Aire expression in experimental acute GVHD. Further work is, however, still required to confirm that such a mechanism is indeed operational in the induction and/or the maintenance of chronic GVHD.

\section{Interventions to improve immune regeneration via protection of thymic epithelium: the role of fibroblast growth factor-7}

Strategies aimed at enhancing thymic function hold the promise to ameliorate post-transplant T-cell immunodeficiency. Both prophylactic and therapeutic approaches may be effective to enhance the (residual) thymic function or, alternatively, (re-) generate new thymic stromal elements. Several strategies to improve immune reconstitution have so far been developed in preclinical models but only few have for now been successfully translated to clinical practice (reviewed in references [4, 12, 213]). Here, interventions shall be discussed that seek to prevent TEC injury after allogeneic HSCT.

Fibroblast growth factor (Fgf)-7 (a.k.a. keratinocyte growth factor) is a potent epithelial cell mitogen that belongs to the large family of the structurally related Fgfs [214]. Fgf7 is currently an approved drug for the prophylaxis of oral mucositis in conditioned transplant recipients $[215,216]$. Its action as a trophic factor and its ability to protect against radio- and chemotherapeutic damage [214] serves as rationale to test the impact of Fgf7 on recovery of TECs following conditioning and HSCT. This concept has received further support by the assumption that the postnatal thymic epithelial compartment may continue to require growth regulating signals including possibly endogenous Fgf7 since postmitotic TECs are continuously replaced by the progeny of immature TEC precursors [38]. Indeed, thymic expression of Fgf7 is sustained throughout life [34]. To exert its biological activity, Fgf7 binds to and activates the IIIb variant of the FgfR2 receptor (FgfR2IIIb) which in the thymus is exclusively expressed on TECs [33, 35, 44, 217]. In response to systemic treatment of normal mice with exogenous Fgf7, the postnatal thymic microenvironment undergoes specific changes. These in vivo alterations are characterized by a robust expansion of both mature and immature TECs within days of Fgf7 exposure even as the 
architectural organization of all TEC populations remains unaltered [35]. Due to an increased proliferation rate following Fgf7 stimulation, the resultant enlargement of the TEC scaffold accommodates a higher lymphoid cellularity while keeping a normal thymocyte-TEC ratio. In addition it is also likely that the exposure of TECs to a pharmacological dose of Fgf7 changes the quality the TEC compartment. In support of such an assumption are results from experimental models where a single course of Fgf7 suffices to reverse the age-related decrease in thymocyte numbers and to restore the architecture and cellular composition of the thymic stromal microenvironment [218]. Moreover, exposure of mice of any age to exogenous Fgf7 also causes an increase in thymopoietic activity and reconstitution of the peripheral T-cell compartment in syngeneic or allogeneic transplant recipients preconditioned with chemo- or radiotherapy [34, 219]. Similarly, rhesus macaques engrafted with autologous HSC and treated with Fgf7 display an enhanced T-cell recovery as assessed by an increase in TREC ${ }^{+}$cells [220]. When used in preclinical models of acute GVHD, the systemic administration of Fgf7 preserves TEC architectural organization, cellularity and function [44]. As a result, normal T-cell development is maintained regardless of alloreactive donor $\mathrm{T}$ cells in the thymus and ongoing GVHD in other typical target organs. In consequence, the administration of Fgf7 prevents the emergence of a repertoire of autoreactive $\mathrm{T}$ cells that promotes the development of experimental chronic GVHD [211]. Exploiting these effects for clinical use, studies are now under way in lymphopenic HSCT recipients to assess whether Fgf7 can enhance T-cell recovery either in the presence or absence of a chemical androgen blockade which is given to further protect TECs [213, 221-223]. Antiandrogen treatment has previously been proposed as an independent measure to correct the transplant-related immune deficiency because the senescence-driven thymic involution has been linked to physiological changes in sex steroid hormone production [42, 224, 225]. Indeed, androgen receptors are expressed on TECs and their binding to sex steroids inhibits thymopoiesis although the molecular mechanisms by which this occurs are not yet precisely known [226]. These data raise reasonable hope that Fgf7 alone or in combination with other agents (such as androgen blockade) can be used to enhance T-cell reconstitution in lymphopenic recipients of allogeneic HSCT.

The molecular mechanisms by which Fgf7 influences TEC function are currently under investigation. Under physiological conditions, Fgf7 is expressed within the thymus both by stromal cells and by $\mathrm{T}$ cells at specific developmental stages [33, 227]. Experiments using both mice deficient in FgfR2IIIb expression or in vitro conditions where mesenchymal cells are physically removed from embryonic thymus lobes have revealed the importance of Fgf signaling during early thymus organogenesis $[33,228,229]$. The postnatal thymic epithelial compartment may, however, continue to require growth-regulating signals, including endogenous Fgf7, whose thymic expression is sustained throughout life. A recent study designed to examine the molecular and cellular mechanisms by which Fgf7 stimulates thymic T lymphopoiesis in normal adult TECs has concluded that FgfR2IIIb is expressed by both mature cortical and medullary as well as immature thymic epithelia [35]. Upon exposure to exogenous Fgf7, these stromal cell subsets proliferate and express several growth and differentiation factors, including different members of the family of Wnt molecules and bone-morphogenetic proteins [35]. In consequence of changes in gene expression in TECs, a robust and sustained increase in thymopoiesis occurs which is initiated as a single wave affecting first the number of the most immature T-cell precursors and subsequently that of more mature thymocytes. This effect of enhanced thymopoiesis is uniquely dependent on the exposure of the stromal microenvironment to $\mathrm{Fgf7}$ as the transfer of the earliest intrathymic T-cell precursor from Fgf7-treated donor mice to naive (i.e. untreated) recipients fails to impart enhanced thymopoiesis and export of mature $\mathrm{T}$ cells to the periphery.

An increase in thymopoiesis and thymic T-cell export appears to be highly beneficial for lymphopenic individuals not at least because the thymus does not sense peripheral $\mathrm{T}$ lymphopenia and is hence unable to gauge its T-cell export accordingly. Consequently, any increase/enhancement in thymic output should positively affect the process of replenishing the peripheral T-cell pool. Enhanced thymic function should also secure a diverse T-cell repertoire as it will concurrently offset an otherwise homeostatic expansion of an only limited number of mature $\mathrm{T}$ cells. Thus, the clinical use of Fgf7 in transplantation medicine may efficiently restore the T-cell compartment and its competence for an effective adaptive immune response. Based on the understanding that interactions between developing thymocytes and TECs determine thymic function, enhanced endogenous production of the cytoprotective Fgf7 may thus constitute an adjunct strategy for the treatment of thymic GVHD. However, expression of Fgf7 is subject to a negative regulation by a standard component of GVHD therapy, namely glucocorticoids, as this drug decreases Fgf7 mRNA in a time- and concentration-dependent manner [229]. The administration of pharmacological doses of Fgf7 prior to conditioning may therefore be needed to compensate at least for the loss of the physiological production of Fgf7 secondary to GVHD prophylaxis with corticosteroids.

\section{Conclusions}

GVHD has traditionally been assessed and graded in the skin, gut, and liver. Growing clinical and mostly experimental evidence now argues that the thymus may actually constitute a 
primary target of allorecognition. The ensuing changes in thymic T-cell maturation and TCR repertoire selection account for both an increased susceptibility for infectious complications and autoimmune pathology typically observed in a population of long-term survivors after allogeneic HSCT. The development of minimally invasive tools for the diagnosis of thymic GVHD (such as advanced imaging or biomarkers) will therefore be needed to monitor strategies that should ameliorate functional damage brought about by GVHD to the processes of T-cell maturation and selection.

\section{References}

1. Mackall CL (2000) T-cell immunodeficiency following cytotoxic antineoplastic therapy: a review. Stem Cells 18:10-18. doi:10.1634/ stemcells.18-1-10

2. Haynes BF, Markert ML, Sempowski GD, Patel DD, Hale LP (2000) The role of the thymus in immune reconstitution in aging, bone marrow transplantation, and HIV-1 infection. Annu Rev Immunol 18:529-560. doi:10.1146/annurev.immunol.18.1.529

3. Weinberg K, Blazar BR, Wagner JE, Agura E, Hill BJ, Smogorzewska M, Koup RA, Betts MR, Collins RH, Douek DC (2001) Factors affecting thymic function after allogeneic hematopoietic stem cell transplantation. Blood 97:1458-166. doi:10.1182/blood.V97.5.1458

4. Van den Brink MR, Alpdogan O, Boyd RL (2004) Strategies to enhance T-cell reconstitution in immunocompromised patients. Nat Rev Immunol 4:856-867. doi:10.1038/nri1484

5. Auletta JJ, Lazarus HM (2005) Immune restoration following hematopoietic stem cell transplantation: an evolving target. Bone Marrow Transplant 35:835-857. doi:10.1038/sj.bmt.1704966

6. Antin JH (2005) Immune reconstitution: the major barrier to successful stem cell transplantation. Biol Blood Marrow Transplant 11:43-45. doi:10.1016/j.bbmt.2004.11.010

7. Muraro PA, Douek DC (2006) Renewing the T cell repertoire to arrest autoimmune aggression. Trends Immunol 27:61-67. doi:10.1016/j.it.2005.12.003

8. Crooks GM, Weinberg K, Mackall C (2006) Immune reconstitution: from stem cells to lymphocytes. Biol Blood Marrow Transplant 12:42-46. doi:10.1016/j.bbmt.2005.10.015

9. Peggs KS (2006) Reconstitution of adaptive and innate immunity following allogeneic hematopoietic stem cell transplantation in humans. Cytotherapy 8:427-436. doi:10.1080/ 14653240600851938

10. Welniak LA, Blazar BR, Murphy WJ (2007) Immunobiology of allogeneic hematopoietic stem cell transplantation. Annu Rev Immunol 25:139-170. doi:10.1146/annurev.immunol.25.022106. 141606

11. Chidgey A, Dudakov J, Seach N, Boyd R (2007) Impact of niche aging on thymic regeneration and immune reconstitution. Semin Immunol 19:331-340. doi:10.1016/j.smim.2007.10.006

12. Zakrzewski JL, Goldberg GL, Smith OM, van den Brink MRM (2008) Enhancing T cell reconstitution after hematopoietic stem cell transplantation: a brief update of the latest trends. Blood Cells Mol Dis 40:44-47. doi:10.1016/j.bcmd.2007.07.015

13. Toubert A (2008) Immune reconstitution after allogeneic HSCT. In Hematopoietic Stem Cell Transplantation. European School of Haematology, Paris

14. Krenger W, Holländer GA (2008) The thymus in GVHD pathophysiology. Best Pract Res Clin Haematol 21:119-128. doi:10.1016/j.beha.2008.02.001
15. Storek J (2008) Immunological reconstitution after hematopoietic cell transplantation - its relation to the contents of the graft. Expert Opin Biol Ther 8:583-597. doi:10.1517/14712598.8.5.583

16. Mackall CL, Granger L, Sheard MA, Cepeda R, Gress RE (1993) T-cell regeneration after bone marrow transplantation: differential CD45 isoform expression on thymic-derived versus thymic-independent progeny. Blood 82:2585-2594

17. Bahceci E, Epperson D, Douek DC, Melenhorst JJ, Childs RC, Barrett AJ (2003) Early reconstitution of the T-cell repertoire after non-myeloablative peripheral blood stem cell transplantation is from post-thymic T-cell expansion and is unaffected by graft-versus-host disease or mixed chimerism. Br J Haematol 122:934-943. doi:10.1046/j.1365-2141.2003.04522.x

18. Fallen PR, McGreavey L, Madrigal JA, Potter M, Ethell M, Prentice HG, Guimaraes A, Travers PJ (2003) Factors affecting reconstitution of the T-cell compartment in allogeneic hematopoietic cell transplant recipients. Bone Marrow Transplant 32:1001-1014. doi:10.1038/sj.bmt.1704235

19. Hakim FT, Memon SA, Cepeda R, Jones EC, Chow CK, Kasten-Sportes C, Odom J, Vance BA, Christensen BL, Mackall CL, Gress RE (2005) Age-dependent incidence, time course, and consequences of thymic renewal in adults. J Clin Invest 115:930-939

20. Gill J, Malin M, Sutherland J, Gray DHD, Holländer GA, Boyd RL (2003) Thymic generation and regeneration. Immunol Rev 195:28-50. doi:10.1034/j.1600-065X.2003.00077.x

21. Guidos C (2006) Thymus and T-lymphocyte development: what is new in the 21st century? Immunol Rev 209:5-9. doi:10.1111/ j.0105-2896.2006.00368.x

22. Holländer G, Gill J, Zuklys S, Iwanami N, Liu C, Takahama Y (2006) Cellular and molecular events during early thymus development. Immunol Rev 209:28-46. doi:10.1111/j.01052896.2006.00357.x

23. Boehm T (2008) Thymus development and function. Curr Opin Immunol 20:1-7. doi:10.1016/j.coi.2008.03.001

24. Rothenberg EV, Moore JE, Yui MA (2008) Launching the T-celllineage developmental programme. Nat Rev Immunol 8:9-21. doi: $10.1038 /$ nri2232

25. Petrie HT, Zúñiga-Pflücker JC (2007) Zoned out: functional mapping of stromal signaling microenvironments in the thymus. Annu Rev Immunol 25:649-679. doi:10.1146/annurev.immu nol.23.021704.115715

26. Anderson G, Lane PJ, Jenkinson EJ (2007) Generating intrathymic microenvironments to establish T-cell tolerance. Nat Rev Immunol 7:954-963. doi:10.1038/nri2187

27. Rodewald HR (2008) Thymus organogenesis. Annu Rev Immunol 26:355-388. doi:10.1146/annurev.immunol.26.021607.090408

28. Van Ewijk W, Wang B, Holländer G, Kawamoto H, Spanopoulou E, Itoi M, Amagai T, Jiang YF, Germeraad WT, Chen WF, Katsura Y (1999) Thymic microenvironments, 3-D versus 2-D? Semin Immunol 11:57-64. doi:10.1006/smim.1998.0158

29. Rodewald HR, Paul S, Haller C, Bluethmann H, Blum C (2001) Thymus medulla consisting of epithelial islets each derived from a single progenitor. Nature 414:763-768. doi:10.1038/414763a

30. Rossi SW, Jenkinson WE, Anderson G, Jenkinson EJ (2006) Clonal analysis reveals a common progenitor for thymic cortical and medullary epithelium. Nature 441:988-991. doi:10.1038/ nature 04813

31. Bleul CC, Corbeaux T, Reuter A, Fisch P, Mönting JS, Boehm T (2006) Formation of a functional thymus initiated by a postnatal epithelial progenitor cell. Nature 441:992-996. doi:10.1038/ nature 04850

32. Jenkinson WE, Rossi SW, Jenkinson EJ, Anderson G (2005) Development of functional thymic epithelial cells occurs independently of lymphostromal interactions. Mech Dev 122:1294-1299. doi:10.1016/j.mod.2005.08.003 
33. Revest JM, Suniara RK, Kerr K, Owen JJ, Dickson C (2001) Development of the thymus requires signaling through the fibroblast growth factor receptor r2-iiib. J Immunol 167:1954161

34. Alpdogan O, Hubbard VM, Smith OM, Patel N, Lu SX, Goldberg GL, Gray DH, Feinman J, Kochman AA, Eng JM, Muriglan SJ, Suh D, Boyd RL, van den Brink MR (2006) Keratinocyte growth factor (KGF) Is required for post-natal thymic regeneration. Blood 107:2453-2460. doi:10.1182/blood2005-07-2831

35. Rossi SW, Jeker LT, Ueno T, Kuse S, Keller MP, Zuklys S, Gudkov AV, Takahama Y, Krenger W, Blazar BR, Holländer GA (2007) Keratinocyte growth factor (KGF) enhances postnatal Tcell development via enhancements in proliferation and function of thymic epithelial cells. Blood 109:3803-3811. doi:10.1182/ blood-2006-10-049767

36. Chu JW, Hakim FT (2007) KGF boosts thymic architecture. Blood 109:3613-3614. doi:10.1182/blood-2007-02-072637

37. Van Ewijk W, Shores EW, Singer A (1994) Crosstalk in the mouse thymus. Immunol Today 15:214-217. doi:10.1016/01675699(94)90246-1

38. Gray D, Seach N, Ueno T, Milton MK, Liston A, Lew AM, Goodnow CC, Boyd RL (2006) Developmental kinetics, turnover, and stimulatory capacity of thymic epithelial cells. Blood 108:3777-3785. doi:10.1182/blood-2006-02-004531

39. Gray D, Abramson J, Benoist C, Mathis D (2007) Proliferative arrest and rapid turnover of thymic epithelial cells expressing Aire. J Exp Med 204:2521-2528. doi:10.1084/jem.20070795

40. Steinmann GG (1986) Changes in the human thymus during aging. Curr Top Pathol 75:43-88

41. Douek DC, McFarland RD, Keiser PH, Gage EA, Massey JM, Haynes BF, Polis MA, Haase AT, Feinberg MB, Sullivan JL, Jamieson BD, Zack JA, Picker LJ, Koup RA (1998) Changes in thymic function with age and during the treatment of HIV infection. Nature 396:690-695. doi:10.1038/25374

42. Taub DD, Longo DL (2005) Insights into thymic aging and regeneration. Immunol Rev 205:72-93. doi:10.1111/j.01052896.2005.00275.x

43. Gray DH, Tull D, Ueno T, Seach N, Classon BJ, Chidgey A, McConville MJ, Boyd RL (2007) A unique thymic fibroblast population revealed by the monoclonal antibody MTS-15. J Immunol 178:4956-4965

44. Rossi S, Blazar BR, Farrell CL, Danilenko DM, Lacey DL, Weinberg KI, Krenger W, Holländer GA (2002) Keratinocyte growth factor preserves normal thymopoiesis and thymic microenvironment during experimental graft-versus-host disease. Blood 100:682-691. doi:10.1182/blood.V100.2.682

45. Anderson MS, Venanzi ES, Klein L, Chen Z, Berzins SP, Turley SJ, von Boehmer H, Bronson R, Dierich A, Benoist C, Mathis D (2002) Projection of an immunological self shadow within the thymus by the Aire protein. Science 298:1395-1401. doi:10.1126/science.1075958

46. Derbinski J, Gabler J, Brors B, Tierling S, Jonnakuty S, Hergenhahn M, Peltonen L, Walter J, Kyewski B (2005) Promiscuous gene expression in thymic epithelial cells is regulated at multiple levels. J Exp Med 202:33-45. doi:10.1084/jem.20050471

47. Kyewski B, Klein L (2006) A central role for central tolerance. Annu Rev Immunol 24:571-606. doi:10.1146/annurev.immunol.23.021704.115601

48. Anderson MS, Venanzi ES, Chen Z, Berzins SP, Benoist C, Mathis D (2005) The cellular mechanism of Aire control of T cell tolerance. Immunity 23:227-239. doi:10.1016/j. immuni.2005.07.005

49. Pereira LE, Bostik P, Ansari AA (2005) The development of mouse APECED models provides new insight into the role of
AIRE in immune regulation. Clin Dev Immunol 12:211-216. doi:10.1080/17402520500212589

50. Park Y, Moon Y, Chung HY (2003) AIRE-1 (autoimmune regulator type 1) as a regulator of the thymic induction of negative selection. Ann N Y Acad Sci 1005:431-435. doi:10.1196/annals.1288.073

51. Liston A, Gray DH, Lesage S, Fletcher AL, Wilson J, Webster KE, Scott HS, Boyd RL, Peltonen L, Goodnow CC (2004) Gene dosage-limiting role of Aire in thymic expression, clonal deletion, and organ-specific autoimmunity. J Exp Med 200:1015-1026. doi:10.1084/jem.20040581

52. Fontenot JD, Rudensky AY (2005) A well adapted regulatory contrivance: regulatory $\mathrm{T}$ cell development and the forkhead family transcription factor Foxp3. Nat Immunol 6:331-337. doi:10.1038/ni1179

53. Von Boehmer H (2005) Mechanisms of suppression by suppressor T cells. Nat Immunol 6:338-344. doi:10.1038/ni1180

54. Miyara M, Sakaguchi S (2007) Natural regulatory T cells: mechanisms of suppression. Trends Mol Med 13:108-116. doi:10.1016/j.molmed.2007.01.003

55. Aschenbrenner K, D'Cruz LM, Vollmann EH, Hinterberger M, Emmerich J, Swee LK, Rolink A, Klein L (2007) Selection of Foxp3+ regulatory $\mathrm{T}$ cells specific for self antigen expressed and presented by Aire $(+)$ medullary thymic epithelial cells. Nat Immunol 8:351-358. doi:10.1038/ni1444

56. Gabor MJ, Scollay R, Godfrey DI (1997) Thymic T cell export is not influenced by the peripheral T cell pool. Eur J Immunol 27:2986-2993. doi:10.1002/eji.1830271135

57. Michie CA, McLean A, Alcock C, Beverley PC (1992) Lifespan of human lymphocyte subsets defined by CD45 isoforms. Nature 360:264-265. doi:10.1038/360264a0

58. Picker LJ, Treer JR, Ferguson-Darnell B, Collins PA, Buck D, Terstappen LW (1993) Control of lymphocyte recirculation in man. I. Differential regulation of the peripheral lymph node homing receptor $\mathrm{L}$-selectin on $\mathrm{T}$ cells during the virgin to memory cell transition. J Immunol 150:1105-1121

59. McFarland RD, Douek DC, Koup RA, Picker LJ (2000) Identification of a human recent thymic emigrant phenotype. Proc Natl Acad Sci USA 97:4215-4220. doi:10.1073/ pnas.070061597

60. Peggs KS, Mackinnon S (2004) Immune reconstitution following hematopoietic stem cell transplantation. $\mathrm{Br} \mathrm{J}$ Haematol 124:407-420. doi:10.1046/j.1365-2141.2003.04767.x

61. Douek DC, Koup RA, McFarland RD, Sullivan JL, Luzuriaga K (2000) Effect of HIV on thymic function before and after antiretroviral therapy in children. J Infect Dis 181:1479-1482. doi: $10.1086 / 315398$

62. Douek DC, Vescio RA, Betts MR, Brenchley JM, Hill BJ, Zhang L, Berenson JR, Collins RH, Koup RA (2000) Assessment of thymic output in adults after haematopoietic stem-cell transplantation and prediction of T-cell reconstitution. Lancet 355:18751881. doi:10.1016/S0140-6736(00)02293-5

63. Patel DD, Gooding ME, Parrott RE, Curtis KM, Haynes BF, Buckley RH (2000) Thymic function after hematopoietic stemcell transplantation for the treatment of severe combined immunodeficiency. N Engl J Med 342:1325-1332. doi:10.1056/ NEJM200005043421804

64. Markert ML, Hicks CB, Bartlett JA, Harmon JL, Hale LP, Greenberg ML, Ferrari G, Ottinger J, Boeck A, Kloster AL, McLaughlin TM, Bleich KB, Ungerleider RM, Lyerly HK, Wilkinson WE, Rousseau FS, Heath-Chiozzi ME, Leonard JM, Haase AT, Shaw GM, Bucy RP, Douek DC, Koup RA, Haynes BF, Bolognesi DP, Weinhold KJ (2000) Effect of highly active antiretroviral therapy and thymic transplantation on immunoreconstitution in HIV infection. AIDS Res Hum Retroviruses 16:403-413. doi:10.1089/088922200309061 
65. Steffens CM, Al-Harthi L, Shott S, Yogev R, Landay A (2000) Evaluation of thymopoiesis using $\mathrm{T}$ cell receptor excision circles (TRECs): differential correlation between adult and pediatric TRECs and naive phenotypes. Clin Immunol 97:95-101. doi:10.1006/clim.2000.4938

66. Storek J, Joseph A, Dawson MA, Douek DC, Storer B, Maloney DG (2002) Factors influencing T-lymphopoiesis after allogeneic hematopoietic cell transplantation. Transplantation 73:11541158. doi:10.1097/00007890-200204150-00026

67. Hochberg EP, Chillemi AC, Wu CJ (2001) Quantitation of T-cell neogenesis in vivo after allogeneic bone marrow transplantation. Blood 98:1116-1121. doi:10.1182/blood.V98.4.1116

68. Lewin SR, Heller G, Zhang L, Rodrigues E, Skulsky E, van den Brink MR, Small TN, Kernan NA, O'Reilly RJ, Ho DD, Young JW (2002) Direct evidence for new T-cell generation by patients after either T-cell-depleted or unmodified allogeneic hematopoietic stem cell transplantation. Blood 100:2235-2242

69. Hakim FT, Gress RE (2002) Reconstitution of thymic function after stem cell transplantation in humans. Curr Opin Hematol 9:490-496. doi:10.1097/00062752-200211000-00004

70. Hazenberg MD, Otto SA, de Pauw ES, Roelofs H, Fibbe WE, Hamann D, Miedema F (2002) T-cell receptor excision circle and T-cell dynamics after allogeneic stem cell transplantation are related to clinical events. Blood 99:3449-353. doi:10.1182/ blood.V99.9.3449

71. Ye P, Kirschner DE (2002) Reevaluation of T cell receptor excision circles as a measure of human recent thymic emigrants. J Immunol 169:4968-4979

72. Svaldi M, Lanthaler AJ, Dugas M, Lohse P, Pescosta N, Straka C, Mitterer M (2003) T-cell receptor excision circles: a novel prognostic parameter for the outcome of transplantation in multiple myeloma patients. Br J Haematol 122:795-801. doi:10.1046/j.1365-2141.2003.04482.x

73. Hazenberg MD, Borghans JA, de Boer RJ, Miedema F (2003) Thymic output: a bad TREC record. Nat Immunol 4:97-99. doi:10.1038/ni0203-97

74. Ribeiro RM, Perelson AS (2007) Determining thymic output quantitatively: using models to interpret experimental T-cell receptor excision circle (TREC) data. Immunol Rev 216:21-34

75. Hockett RD, Nunez G, Korsmeyer SJ (1989) Evolutionary comparison in murine and human delta T-cell receptor deleting elements. New Biol 1:266-274

76. Verschuren MC, Wolvers-Tettero IL, Breit TM, Noordzij J, van Wering ER, van Dongen JJ (1997) Preferential rearrangements of the $\mathrm{T}$ cell receptor-delta-deleting elements in human $\mathrm{T}$ cells. $\mathrm{J}$ Immunol 158:1208-1216

77. Poulin JF, Sylvestre M, Champagne P, Dion ML, Kettaf N, Dumont A, Lainesse M, Fontaine P, Roy DC, Perreault C, Sekaly RP, Cheynier R (2003) Evidence for adequate thymic function but impaired naive T-cell survival following allogeneic hematopoietic stem cell transplantation in the absence of chronic graft-versus-host disease. Blood 102:4600-4607. doi:10.1182/blood-2003-05-1428

78. Jamieson BD, Douek DC, Killian S, Hultin LE, Scripture-Adams DD, Giorgi JV, Marelli D, Koup RA, Zack JA (1999) Generation of functional thymocytes in the human adult. Immunity 10:569575. doi:10.1016/S1074-7613(00)80056-4

79. Douek DC, Koup RA (2000) Evidence for thymic function in the elderly. Vaccine 18:1638-1641. doi:10.1016/S0264-410X(99) 00499-5

80. Ortman CL, Dittmar KA, Witte PL, Le PT (2002) Molecular characterization of the mouse involuted thymus: aberrations in expression of transcription regulators in thymocyte and epithelial compartments. Int Immunol 14:813-822. doi:10.1093/intimm/ dxf042

81. Hakim FT, Gress RE (2005) Reconstitution of the lymphocyte compartment after lymphocyte depletion: a key issue in clinical immunology. Eur J Immunol 35:3099-3102. doi:10.1002/ eji.200535385

82. Williams KM, Hakim FT, Gress RE (2007) T cell immune reconstitution following lymphodepletion. Semin Immunol 19:318-330. doi:10.1016/j.smim.2007.10.004

83. Jameson SC (2005) T cell homeostasis: keeping useful T cells alive and live $\mathrm{T}$ cells useful. Semin Immunol 17:231-237. doi:10.1016/j.smim.2005.02.003

84. Scollay R, Godfrey DI (1995) Thymic emigration: conveyor belts or lucky dips? Immunol Today 16:268-273. doi:10.1016/ 0167-5699(95)80179-0

85. Gorski J, Yassai M, Zhu X, Kissela B, Kissella B [corrected to Kissela B, Keever C, Flomenberg N (1994) Circulating T cell repertoire complexity in normal individuals and bone marrow recipients analyzed by CDR3 size spectratyping. Correlation with immune status. J Immunol 152:5109-5119

86. Sato K, Ohtsuka K, Hasegawa K, Yamagiwa S, Watanabe H, Asakura H, Abo T (1995) Evidence for extrathymic generation of intermediate $\mathrm{T}$ cell receptor cells in the liver revealed in thymectomized, irradiated mice subjected to bone marrow transplantation. J Exp Med 182:759-767. doi:10.1084/jem.182.3.759

87. Heitger A, Neu N, Kern H, Panzer-Grumayer ER, Greinix H, Nachbaur D, Niederwieser D, Fink FM (1997) Essential role of the thymus to reconstitute naive (CD45RA+) T-helper cells after human allogeneic bone marrow transplantation. Blood 90:850-857

88. Heitger A, Greinix H, Mannhalter C, Mayerl D, Kern H, Eder J, Fink FM, Niederwieser D, Panzer-Grumayer ER (2000) Requirement of residual thymus to restore normal T-cell subsets after human allogeneic bone marrow transplantation. Transplantation 69:2366-273. doi:10.1097/00007890-200006150-00026

89. Klein AK, Patel DD, Gooding ME, Sempowski GD, Chen BJ, Liu C, Kurtzberg J, Haynes BF, Chao NJ (2001) T-Cell recovery in adults and children following umbilical cord blood transplantation. Biol Blood Marrow Transplant 7:454-466. doi:10.1016/ S1083-8791(01)80013-6

90. Chen X, Barfield R, Benaim E, Leung W, Knowles J, Lawrence D, Otto M, Shurtleff SA, Neale GA, Behm FG, Turner V, Handgretinger R (2005) Prediction of T-cell reconstitution by assessment of T-cell receptor excision circle before allogeneic hematopoietic stem cell transplantation in pediatric patients. Blood 105:886-893. doi:10.1182/blood-2004-04-1405

91. Benz C, Martins VC, Radtke F, Bleul CC (2008) The stream of precursors that colonizes the thymus proceeds selectively through the early $\mathrm{T}$ lineage precursor stage of $\mathrm{T}$ cell development. J Exp Med 205:1187-1199. doi:10.1084/jem.20072168

92. Weinberg K, Annett G, Kashyap A, Lenarsky C, Forman SJ, Parkman R (1995) The effect of thymic function on immunocompetence following bone marrow transplantation. Biol Blood Marrow Transplant 1:18-23

93. Kook H, Goldman F, Padley D, Giller R, Rumelhart S, Holida M, Lee N, Peters C, Comito M, Huling D, Trigg M (1996) Reconstruction of the immune system after unrelated or partially matched T-cell-depleted bone marrow transplantation in children: immunophenotypic analysis and factors affecting the speed of recovery. Blood 88:1089-1097

94. Dumont-Girard F, Roux E, van Lier RA, Hale G, Helg C, Chapuis B, Starobinski M, Roosnek E (1998) Reconstitution of the T-cell compartment after bone marrow transplantation: restoration of the repertoire by thymic emigrants. Blood 92:4464-4471

95. Small TN, Papadopoulos EB, Boulad F, Black P, Castro-Malaspina H, Childs BH, Collins N, Gillio A, George D, Jakubowski A, Heller G, Fazzari M, Kernan N, MacKinnon S, Szabolcs P, Young JW, O'Reilly RJ (1999) Comparison of immune reconstitution after unrelated and related T-cell- depleted bone marrow transplantation: effect of patient age and donor leukocyte infusions. Blood 93:467-480 
96. Douek DC (2002) The contribution of the thymus to immune reconstitution after hematopoietic stem-cell transplantation. Cytotherapy 4:425-426. doi:10.1080/146532402320776035

97. Roux E, Dumont-Girard F, Starobinski M, Siegrist CA, Helg C, Chapuis B, Roosnek E (2000) Recovery of immune reactivity after T-cell-depleted bone marrow transplantation depends on thymic activity. Blood 96:2299-2303

98. Storek J, Dawson MA, Storer B, Stevens-Ayers T, Maloney DG, Marr KA, Witherspoon RP, Bensinger W, Flowers ME, Martin P, Storb R, Appelbaum FR, Boeckh M (2001) Immune reconstitution after allogeneic marrow transplantation compared with blood stem cell transplantation. Blood 97:3380-339. doi:10.1182/blood.V97.11.3380

99. Muraro PA, Douek DC, Packer A, Chung K, Guenaga FJ, Cassiani-Ingoni R, Campbell C, Memon S, Nagle JW, Hakim FT, Gress RE, McFarland HF, Burt RK, Martin R (2005) Thymic output generates a new and diverse TCR repertoire after autologous stem cell transplantation in multiple sclerosis patients. J Exp Med 201:805-816. doi:10.1084/jem.20041679

100. Fry TJ, Mackall CL (2005) Immune reconstitution following hematopoietic progenitor cell transplantation: challenges for the future. Bone Marrow Transplant 35(Suppl 1):S53-S57. doi:10.1038/sj.bmt.1704848

101. Clave E, Rocha V, Talvensaari K, Busson M, Douay C, Appert ML, Rabian C, Carmagnat M, Garnier F, Filion A, Socie G, Gluckman E, Charron D, Toubert A (2005) Prognostic value of pretransplantation host thymic function in HLA-identical sibling hematopoietic stem cell transplantation. Blood 105:2608-2613. doi:10.1182/blood-2004-04-1667

102. Pannetier C, Cochet M, Darche S, Casrouge A, Zöller M, Kourilsky P (1993) The sizes of the CDR3 hypervariable regions of the murine T-cell receptor beta chains vary as a function of the recombined germ-line segments. Proc Natl Acad Sci U S A 90:4319-4323. doi:10.1073/pnas.90.9.4319

103. Mackall CL, Gress RE (1997) Pathways of T-cell regeneration in mice and humans: implications for bone marrow transplantation and immunotherapy. Immunol Rev 157:61-72. doi:10.1111/ j.1600-065X.1997.tb00974.x

104. Mackall CL, Hakim FT, Gress RE (1997) T-cell regeneration: all repertoires are not created equal. Immunol Today 18:245-251. doi:10.1016/S0167-5699(97)81664-7

105. Roux E, Helg C, Dumont-Girard F, Chapuis B, Jeannet M, Roosnek E (1996) Analysis of T-cell repopulation after allogeneic bone marrow transplantation: significant differences between recipients of T-cell depleted and unmanipulated grafts. Blood 87:3984-3992

106. Talvensaari K, Clave E, Douay C, Rabian C, Garderet L, Busson M, Garnier F, Douek D, Gluckman E, Charron D, Toubert A (2002) A broad T-cell repertoire diversity and an efficient thymic function indicate a favorable long-term immune reconstitution after cord blood stem cell transplantation. Blood 99:1458-1464. doi:10.1182/blood.V99.4.1458

107. Hentschke P, Omazic B, Mattsson J, Näsman-Björk I, Lundkvist I, Gigliotti D, Barkholt L, Ringdén O, Remberger M (2005) Tcell receptor Vbeta repertoire after myeloablative and reduced intensity conditioning allogeneic haematopoietic stem cell transplantation. Scand J Immunol 61:285-294. doi:10.1111/ j.1365-3083.2005.01564.x

108. Godthelp BC, van Tol MJ, Vossen JM, van Den Elsen PJ (1999) T-cell immune reconstitution in pediatric leukemia patients after allogeneic bone marrow transplantation with T-cell-depleted or unmanipulated grafts: evaluation of overall and antigen-specific T-cell repertoires. Blood 94:4358-4369

109. Eyrich M, Croner T, Leiler C, Lang P, Bader P, Klingebiel T, Niethammer D, Schlegel PG (2002) Distinct contributions of CD4+ and CD8+ naive and memory T-cell subsets to overall T-cell-receptor repertoire complexity following transplantation of T-cell-depleted CD34-selected hematopoietic progenitor cells from unrelated donors. Blood 100:1915-1918. doi:10.1182/blood-2001-11-0005

110. Dey BR, Spitzer TR (2006) Current status of haploidentical stem cell transplantation. Br J Haematol 135:423-437. doi:10.1111/ j.1365-2141.2006.06300.x

111. Koh LP, Chao NJ (2008) Nonmyeloablative allogeneic hematopoietic stem cell transplant using mismatched/haploidentical donors: a review. Blood Cells Mol Dis 40:20-24. doi:10.1016/ j.bcmd.2007.06.017

112. Aversa F (2008) Haploidentical haematopoietic stem cell transplantation for acute leukaemia in adults: experience in Europe and the United States. Bone Marrow Transplant 41:473481. doi:10.1038/sj.bmt.1705966

113. Laufer TM, DeKoning J, Markowitz JS, Lo D, Glimcher LH (1996) Unopposed positive selection and autoreactivity in mice expressing class II MHC only on thymic cortex. Nature 383:8185. doi: $10.1038 / 383081 \mathrm{a} 0$

114. Laufer TM, Fan L, Glimcher LH (1999) Self-reactive T cells selected on thymic cortical epithelium are polyclonal and are pathogenic in vivo. J Immunol 162:5078-5084

115. Tivol E, Komorowski R, Drobyski WR (2005) Emergent autoimmunity in graft-versus-host disease. Blood 105:48854891. doi:10.1182/blood-2004-12-4980

116. Teshima T, Reddy P, Liu C, Williams DA, KCooke KR, Ferrara JLM (2003) Impaired thymic negative selection causes autoimmune graft-versus-host disease. Blood 102:429-435. doi:10.1182/blood-2003-01-0266

117. Sakoda Y, Hashimoto D, Asakura S, Takeuchi K, Harada M, Tanimoto M, Teshima T (2007) Donor-derived thymic-dependent T cells cause chronic graft-versus-host disease. Blood 109:17561764. doi:10.1182/blood-2006-08-042853

118. Knobloch C, Friedrich W (1991) T cell receptor diversity in severe combined immunodeficiency following HLA-haploidentical bone marrow transplantation. Bone Marrow Transplant $8: 383-387$

119. Haddad E, Landais P, Friedrich W, Gerritsen B, Cavazzana-Calvo M, Morgan G, Bertrand Y, Fasth A, Porta F, Cant A, Espanol T, Müller S, Veys P, Vossen J, Fischer A (1998) Long-term immune reconstitution and outcome after HLA-nonidentical Tcell-depleted bone marrow transplantation for severe combined immunodeficiency: a European retrospective study of 116 patients. Blood 91:3646-3653

120. Sarzotti M, Patel DD, Li X, Ozaki DA, Cao S, Langdon S, Parrott RE, Coyne K, Buckley RH (2003) T cell repertoire development in humans with SCID after nonablative allogeneic marrow transplantation. J Immunol 170:2711-2718

121. Woodard P, Cunningham JM, Benaim E, Chen X, Hale G, Horwitz E, Houston J, Kasow K, Leung W, Wang W, Yusuf U, Handgretinger R (2004) Effective donor lymphohematopoietic reconstitution after haploidentical CD34+ -selected hematopoietic stem cell transplantation in children with refractory severe aplastic anemia. Bone Marrow Transplant 33:411-418. doi:10.1038/sj.bmt. 1704358

122. Chen X, Hale GA, Barfield R, Benaim E, Leung WH, Knowles J, Horwitz EM, Woodard P, Kasow K, Yusuf U, Behm FG, Hayden RT, Shurtleff SA, Turner V, Srivastava DK, Handgretinger R (2006) Rapid immune reconstitution after a reduced-intensity conditioning regimen and a CD3-depleted haploidentical stem cell graft for paediatric refractory haematological malignancies. Br J Haematol 135:524-532. doi:10.1111/j.13652141.2006.06330.x

123. Friedrich W, Hönig M, Müller SM (2007) Long-term follow-up in patients with severe combined immunodeficiency treated by bone marrow transplantation. Immunol Res 38:165-173. doi:10.1007/s12026-007-0030-2 
124. Fu YW, Wu de P, Cen JN, Feng YF, Chang WR, Zhu ZL, Qiu QC, Zhu P (2007) Patterns of T-cell reconstitution by assessment of T-cell receptor excision circle and T-cell receptor clonal repertoire after allogeneic hematopoietic stem cell transplantation in leukemia patients-a study in Chinese patients. Eur J Haematol 79:138-145. doi:10.1111/j.1600-0609.2007.00885.x

125. Touraine JL, Plotnicky H, Roncarolo MG, Bacchetta R, Gebuhrer L (2007) Immunological lessons learnt from patients transplanted with fully mismatched stem cells. Immunol Res 38:201-209. doi:10.1007/s12026-007-0002-6

126. Verfuerth S, Peggs K, Vyas P, Barnett L, O'Reilly RJ, Mackinnon S (2000) Longitudinal monitoring of immune reconstitution by CDR3 size spectratyping after T-cell-depleted allogeneic bone marrow transplant and the effect of donor lymphocyte infusions on T-cell repertoire. Blood 95:3990-3995

127. Hashimoto F, Sugiura K, Inoue K, Ikehara S (1997) Major histocompatibility complex restriction between hematopoietic stem cells and stromal cells in vivo. Blood 89:49-54

128. Zinkernagel RM, Althage A (1999) On the role of thymic epithelium vs. bone marrow-derived cells in repertoire selection of T cells. Proc Natl Acad Sci U S A 96:8092-8097. doi:10.1073/pnas.96.14.8092

129. Vukmanovic S (1992) Positive selection of $\mathrm{T}$ lymphocytes induced by intrathymic injection of a thymic epithelial cell line. Nature 359:729-732. doi:10.1038/359729a0

130. Hugo P, Kappler JW, McCormack JE, Marrack P (1993) Fibroblasts can induce thymocyte positive selection in vivo. Proc Natl Acad Sci U S A 90:10335-10339. doi:10.1073/pnas.90.21.10335

131. Pawlowski T, Elliott JD, Loh DY, Staerz UD (1993) Positive selection of T lymphocytes on fibroblasts. Nature 364:642-645. doi:10.1038/364642a0

132. Choi EY, Jung KC, Park HJ, Chung DH, Song JS, Yang SD, Simpson E, Park SH (2005) Thymocyte-thymocyte interaction for efficient positive selection and maturation of CD4 T cells. Immunity 23:387-396. doi:10.1016/j.immuni.2005.09.005

133. Martinic MM, Rülicke T, Althage A, Odermatt B, Höchli M, Lamarre A, Dumrese T, Speiser DE, Kyburz D, Hengartner H, Zinkernagel RM (2003) Efficient T cell repertoire selection in tetraparental chimeric mice independent of thymic epithelial MHC. Proc Natl Acad Sci U S A 100:1861-1866. doi:10.1073/ pnas. 252641399

134. Markert ML, Boeck A, Hale LP, Kloster AL, McLaughlin TM, Batchvarova MN, Douek DC, Koup RA, Kostyu DD, Ward FE, Rice HE, Mahaffey SM, Schiff SE, Buckley RH, Haynes BF (1999) Transplantation of thymus tissue in complete DiGeorge syndrome. N Engl J Med 341:1180-1189. doi:10.1056/ NEJM199910143411603

135. Markert ML, Devlin BH, Alexieff MJ, Li J, McCarthy EA, Gupton SE, Chinn IK, Hale LP, Kepler TB, He M, Sarzotti M, Skinner MA, Rice HE, Hoehner JC (2007) Review of 54 patients with complete DiGeorge anomaly enrolled in protocols for thymus transplantation: outcome of 44 consecutive transplants. Blood 109:4539-4547. doi:10.1182/blood-2006-10-048652

136. Markert ML, Kostyu DD, Ward FE, McLaughlin TM, Watson TJ, Buckley RH, Schiff SE, Ungerleider RM, Gaynor JW, Oldham KT, Mahaffey SM, Ballow M, Driscoll DA, Hale LP, Haynes BF (1997) Successful formation of a chimeric human thymus allograft following transplantation of cultured postnatal human thymus. J Immunol 158:998-1005

137. Blazar BR, Murphy WJ (2005) Bone marrow transplantation and approaches to avoid graft-versus-host disease (GVHD). Philos Trans R Soc Lond B Biol Sci 360:1747-1767. doi:10.1098/ rstb.2005.1701

138. Deeg HJ, Antin JH (2006) The clinical spectrum of acute graftversus-host disease. Semin Hematol 43:24-31. doi:10.1053/j. seminhematol.2005.09.003
139. Ferrara JLM (2007) Novel strategies for the treatment and diagnosis of graft-versus-host disease. Best Pract Res Clin Haematol 20:91-97. doi:10.1016/j.beha.2006.11.004

140. Weisdorf D (2007) GVHD the nuts and bolts. Hematology (Am Soc Hematol Educ Program) 2007:62-67. doi:10.1182/asheducation2007.1.62

141. Bacigalupo A (2007) Management of acute graft-versus-host disease. Br J Haematol 137:87-98. doi:10.1111/j.1365-2141.2007. 06533.x

142. Morris ES, Hill GR (2007) Advances in the understanding of acute graft-versus-host disease. Br J Haematol 137:3-19

143. Ferrara JLM (2006) GVHD: in vivo veritas. Blood 106:772-773. doi:10.1182/blood-2005-05-1925

144. Ochs L, Shu XO, Miller J, Enright H, Wagner J, Filipovich A, Miller W, Weisdorf D (1995) Late infections after allogeneic bone marrow transplantations: comparison of incidence in related and unrelated donor transplant recipients. Blood 86:3979-3986

145. Wu CJ, Chillemi A, Alyea EP, Orsini E, Neuberg D, Soiffer RJ, Ritz J (2000) Reconstitution of T-cell receptor repertoire diversity following T-cell depleted allogeneic bone marrow transplantation is related to hematopoietic chimerism. Blood 95:352-359

146. Weinberg KI (2007) Protection from posttransplantation immune deficiency? Blood 109:3617-3618. doi:10.1182/blood-2007-02073064

147. Gratwohl A, Baldomero H, Frauendorfer K, Urbano-Ispizua A, Niederwieser D (2007) Results of the EBMT activity survey 2005 on haematopoietic stem cell transplantation: focus on increasing use of unrelated donors. Bone Marrow Transplant 39:71-87. doi:10.1038/sj.bmt.1705555

148. Sale GE, Alavaikko M, Schaefers KM, Mahan CT (1992) Abnormal CD4:CD8 ratios and delayed germinal center reconstitution in lymph nodes of human graft recipients with graftversus-host disease (GVHD): an immunohistological study. Exp Hematol 20:1017-1021

149. Beschorner WE, Hutchins GM, Elfenbein GJ, Santos GW (1978) The thymus in patients with allogeneic bone marrow transplants. Am J Pathol 92:173-181

150. Seddik M, Seemayer TA, Lapp WS (1980) T cell functional defect associated with thymic epithelial cell injury induced by a graft-versus-host reaction. Transplantation 29:61-66. doi:10.1097/00007890-198001000-00013

151. Seemayer TA, Lapp WS, Bolande RP (1978) Thymic epithelial injury in graft-versus-host reactions following adrenalectomy. Am J Pathol 93:325-338

152. Lapp WS, Ghayur T, Mendez M, Seddik M, Seemeyer TA (1985) The functional and histological basis for graft-versushost-induced immunosuppression. Immunol Rev 88:107-133. doi:10.1111/j.1600-065X.1985.tb01155.x

153. Ghayur T, Seemayer T, Lapp WS (1990) Histologic correlates of immune functional deficits in graft-vs-host disease. In: Burakoff SJ, Deeg HJ, Ferrara J, Atkinson K (eds) Graft-vs.-Host Disease: Immunology, Pathophysiology, and Treatment. Marcel Dekker, New York, pp 109-132

154. Seemayer TA, Bolande RP (1980) Thymic involution mimicking thymic dysplasia: a consequence of transfusion-induced graft versus host disease in a premature infant. Arch Pathol Lab Med 104:141-144

155. Gartner JG (1991) Thymic involution with loss of Hassall's corpuscles mimicking thymic dysplasia in a child with transfusion-associated graft-versus-host disease. Pediatr Pathol 11:449 456. doi:10.3109/15513819109064780

156. Przybylski GK, Kreuzer KA, Siegert W, Schmidt CA (2007) No recovery of T-cell receptor excision circles (TRECs) after non-myeloablative allogeneic hematopoietic stem cell trans- 
plantation is correlated with the onset of GVHD. J Appl Genet 48:397-404

157. Krenger W, Schmidlin H, Cavadini G, Holländer GA (2004) On the relevance of TCR rearrangement circles as molecular markers for thymic output during experimental graft-versus-host disease. J Immunol 172:7359-7367

158. Krenger W, Ferrara JL (1996) Graft-versus-host disease and the Th1/Th2 paradigm. Immunol Res 15:50-73. doi:10.1007/ BF02918284

159. Krenger W, Hill GR, Ferrara JL (1997) Cytokine cascades in acute graft-versus-host disease. Transplantation 64:553-558. doi:10.1097/00007890-199708270-00001

160. Hill GR, Ferrara JL (2000) The primacy of the gastrointestinal tract as a target organ of acute graft-versus-host disease: rationale for the use of cytokine shields in allogeneic bone marrow transplantation. Blood 95:2754-2759

161. Reddy P, Ferrara JL (2003) Immunobiology of acute graftversus-host disease. Blood Rev 17:187-194. doi:10.1016/S0268960X(03)00009-2

162. Wysocki CA, Panoskaltsis-Mortari A, Blazar BR, Serody JS (2005) Leukocyte migration and graft-versus-host disease. Blood 105:4191-4199. doi:10.1182/blood-2004-12-4726

163. Ferrara JL, Reddy P (2006) Pathophysiology of graft-versus-host disease. Semin Hematol 43:3-10. doi:10.1053/j.seminhematol. 2005.09.001

164. Shlomchik WD (2007) Graft-versus-host disease. Nat Rev Immunol 7:340-352. doi:10.1038/nri2000

165. Riddell SR, Appelbaum FR (2007) Graft-versus-host disease: a surge of developments. PLoS Med 4:1174-1177. doi:10.1371/ journal.pmed.0040198

166. Via CS, Sharrow SO, Shearer GM (1987) Role of cytotoxic T lymphocytes in the prevention of lupus-like disease occurring in a murine model of graft-versus-host disease. J Immunol 139:1840-1849

167. Via CS, Finkelman FD (1993) Critical role of interleukin-2 in the development of acute graft-versus-host disease. Int Immunol 5:565-572. doi:10.1093/intimm/5.6.565

168. Via CS, Rus V, Gately MK, Finkelman FD (1994) IL-12 stimulates the development of acute graft-versus-host disease in mice that would normally develop chronic, autoimmune graftversus-host disease. J Immunol 153:4040

169. Garside P, Reid S, Steel M, Mowat AM (1994) Differential cytokine production associated with distinct phases of murine graft-versus-host reaction. Immunology 82:211-214

170. Krenger W, Snyder KM, Byon JC, Falzarano G, Ferrara JL (1995) Polarized type 2 alloreactive CD4+ and CD8+ donor T cells fail to induce experimental acute graft-versus-host disease. $\mathrm{J}$ Immunol 155:585-593

171. Krenger W, Falzarano G, Delmonte J, Snyder KM, Byon JC, Ferrara JL (1996) Interferon-gamma suppresses T-cell proliferation to mitogen via the nitric oxide pathway during experimental acute graft-versus-host disease. Blood 88:1113-1121

172. Krenger W, Rossi S, Piali L, Holländer GA (2000) Thymic atrophy in murine acute graft-versus-host disease is effected by impaired cell cycle progression of host pro-T and pre-T cells. Blood 96:347-354

173. Hauri-Hohl MM, Keller MP, Gill J, Hafen K, Pachlatko E, Boulay T, Peter A, Holländer GA, Krenger W (2007) Donor Tcell alloreactivity against host thymic epithelium limits T-cell development after bone marrow transplantation. Blood 109:4080-4088. doi:10.1182/blood-2006-07-034157

174. Seemayer TA, Lapp WS, Bolande RP (1977) Thymic involution in murine graft-versus-host reaction. Epithelial injury mimicking human thymic dysplasia. Am J Pathol 88:119-133

175. Fukuzawa M, Via CS, Shearer GM (1988) Defective thymic education of L3T4+ T helper cell function in graft-vs-host mice. J Immunol 141:430-439
176. Ghayur T, Seemayer TA, Xenocostas A, Lapp WS (1988) Complete sequential regeneration of graft-vs.-host-induced severely dysplastic thymuses. Implications for the pathogenesis of chronic graft- vs.-host disease. Am J Pathol 133:39-46

177. Fukushi N, Arase H, Wang B, Ogasawara K, Gotohda T, Good RA, Onoe K (1990) Thymus: a direct target tissue in graftversus-host reaction after allogeneic bone marrow transplantation that results in abrogation of induction of self-tolerance. Proc Natl Acad Sci U S A 87:6301-6305. doi:10.1073/pnas.87.16.6301

178. Desbarats J, Lapp WS (1993) Thymic selection and thymic major histocompatibility complex class II expression are abnormal in mice undergoing graft-versus-host reactions. J Exp Med 178:805-814. doi:10.1084/jem.178.3.805

179. Holländer GA, Widmer B, Burakoff SJ (1994) Loss of normal thymic repertoire selection and persistence of autoreactive $T$ cells in graft vs. host disease. J Immunol 152:1609-1617

180. Dulude G, Roy DC, Perreault C (1999) The effect of graftversus-host disease on $\mathrm{T}$ cell production and homeostasis. J Exp Med 189:1329-1342. doi:10.1084/jem.189.8.1329

181. Van den Brink MR, Moore E, Ferrara JL, Burakoff SJ (2000) Graft-versus-host-disease-associated thymic damage results in the appearance of $\mathrm{T}$ cell clones with anti-host reactivity. Transplantation 69:446-449. doi:10.1097/00007890-200002150-00026

182. Morohashi T, Ogasawara K, Kitaichi N, Iwabuchi K, Onoé K (2000) Abrogation of negative selection by GVHR induced by minor histocompatibility antigens or $\mathrm{H}-2 \mathrm{D}$ antigen alone. Immunobiology 202:268-279

183. Krenger W, Rossi S, Holländer GA (2000) Apoptosis of thymocytes during acute graft-versus-host disease is independent of glucocorticoids. Transplantation 69:2190-2193. doi:10.1097/ 00007890-200005270-00040

184. Huiskamp R, van Ewijk W (1985) Repopulation of the mouse thymus after sublethal fission neutron irradiation. I. Sequential appearance of thymocyte subpopulations. J Immunol 134:21612219

185. Huiskamp R, Davids JA, van Ewijk W (1988) The effect of graded doses of fission neutrons or $\mathrm{X}$ rays on the stromal compartment of the thymus in mice. Radiat Res 113:25-39. doi:10.2307/3577177

186. Kumamoto T, Inaba M, Toki J, Adachi Y, Imamura H, Ikehara S (1995) Cytotoxic effects of irradiation and deoxyguanosine on fetal thymus. Immunobiology 192:365-381

187. Gleichmann E, Pals ST, Rolink AG, Radaskiewicz T, Gleichmann H (1984) Graft-versus-host reactions: clues to the etiopathology of a spectrum of immunological diseases. Immunol Today 5:324. doi:10.1016/0167-5699(84)90126-9

188. Godfrey DI, Kennedy J, Suda T, Zlotnik A (1993) A developmental pathway involving four phenotypically and functionally distinct substes of CD3-CD4-CD8- triple-negative adult mouse thymocytes defined by CD44 and CD25 expression. J Immunol 150:4244-4252

189. Penit C, Lucas B, Vasseur F (1995) Cell expansion and growth arrest phases during the transition from precursor (CD4-8-) to immature $(\mathrm{CD} 4+8+)$ thymocytes in normal and genetically modified mice. J Immunol 154:5103-5513

190. Wyllie AH (1980) Glucocorticoid-induced thymocyte apoptosis is associated with endogenous endonuclease activation. Nature 284:555-556. doi: $10.1038 / 284555 \mathrm{a} 0$

191. Khairallah M, Spach C, Maitre F, Motta R (1988) Endocrine involvement in minor (non-H-2) graft versus host reaction in mice: dissociated effect on corticosterone and aldosterone plasma levels. Endocrinology 123:1949-1954

192. Kornbluth M, You-Ten E, Desbarats J, Gamache S, Xenocostas A, Lapp WS (1991) T cell subsets in the thymus of graft-versushost immunosuppressed mice. Sensitivity of the L3T4+Lyt-2subset to cortisone. Transplantation 51:262-267. doi:10.1097/ 00007890-199101000-00044 
193. You-Ten KE, Lapp WS (1996) The role of endogenous glucocorticoids on host $\mathrm{T}$ cell populations in the peripheral lymphoid organs of mice with graft-versus-host disease. Transplantation 61:76-83. doi:10.1097/00007890-199601150-00016

194. Gao EK, Kosaka H, Surh CD, Sprent J (1991) T cell contact with Ia antigens on nonhemopoietic cells in vivo can lead to immunity rather than tolerance. J Exp Med 174:435-446. doi:10.1084/ jem.174.2.435

195. Kosaka H, Surh CD, Sprent J (1992) Stimulation of mature unprimed CD8 $+\mathrm{T}$ cells by semiprofessional antigen-presenting cells in vivo. J Exp Med 176:1291-1302. doi:10.1084/jem.176.5.1291

196. Dakic A, Shao QX, D'Amico A, O'Keeffe M, Chen WF, Shortman K, Wu L (2004) Development of the dendritic cell system during mouse ontogeny. J Immunol 172:1018-1027

197. Pimenta-Araujo R, Mascarell L, Huesca M, Cumano A, Bandeira A (2001) Embryonic thymic epithelium naturally devoid of APCs is acutely rejected in the absence of indirect recognition. $\mathrm{J}$ Immunol 167:5034-5041

198. Yang SJ, Ahn S, Park CS, Holmes KL, Westrup J, Chang CH, Kim MG (2006) The quantitative assessment of MHC II on thymic epithelium: implications in cortical thymocyte development. Int Immunol 18:729-739. doi:10.1093/intimm/dx1010

199. Michie SA, Kirkpatrick EA, Rouse RV (1988) Rare peripheral T cells migrate to and persist in normal mouse thymus. J Exp Med 168:1929-1934. doi:10.1084/jem.168.5.1929

200. Agus D, Surh C, Sprent J (1991) Reentry of T cells to the adult thymus is restricted to activated T cells. J Exp Med 173:10391046. doi:10.1084/jem.173.5.1039

201. Surh CD, Sprent J, Webb SR (1993) Exclusion of circulating T cells from the thymus does not apply in the neonatal period. $\mathrm{J}$ Exp Med 177:379-385. doi:10.1084/jem.177.2.379

202. Westermann J, Smith T, Peters U, Tschernig T, Pabst R, Steinhoff G, Sparshott SM, Bell EB (1996) Both activated and nonactivated leukocytes from the periphery continuously enter the thymic medulla of adult rats: phenotypes, sources and magnitude of traffic. Eur J Immunol 26:1866-1874. doi:10.1002/eji.1830260830

203. Daikeler T, Tyndall A (2007) Autoimmunity following haematopoietic stem-cell transplantation. Best Pract Res Clin Haematol 20:349-360. doi:10.1016/j.beha.2006.09.008

204. Filipovich AH, Weisdorf D, Pavletic S, Socie G, Wingard JR, Lee SJ, Martin P, Chien J, Przepiorka D, Couriel D, Cowen EW, Dinndorf P, Farrell A, Hartzman R, Henslee-Downey J, Jacobsohn D, McDonald G, Mittleman B, Rizzo JD, Robinson M, Schubert M, Schultz K, Shulman H, Turner M, Vogelsang G, Flowers ME (2005) National Institutes of Health consensus development project on criteria for clinical trials in chronic graftversus-host disease: I. Diagnosis and staging working group report. Biol Blood Marrow Transplant 11:945-956. doi:10.1016/ j.bbmt.2005.09.004

205. Mackey JR, Desai S, Larratt L, Cwik V, Nabholtz JM (1997) Myasthenia gravis in association with allogeneic bone marrow transplantation: clinical observations, therapeutic implications and review of literature. Bone Marrow Transplant 19:939-942. doi:10.1038/sj.bmt.1700759

206. Chu YW, Gress RE (2008) Murine models of chronic graft-versushost disease: insights and unresolved issues. Biol Blood Marrow Transplant 14:365-378. doi:10.1016/j.bbmt.2007.12.002

207. McCormick LL, Zhang Y, Tootell E, Gilliam AC (1999) AntiTGF-beta treatment prevents skin and lung fibrosis in murine sclerodermatous graft-versus-host disease: a model for human scleroderma. J Immunol 163:5693-5699

208. Zhang C, Todorov I, Zhang Z, Liu Y, Kandeel F, Forman S, Strober S, Zeng D (2006) Donor CD4+ T and B cells in transplants induce chronic graft-versus-host disease with autoimmune manifestations. Blood 107:2993-3001. doi:10.1182/ blood-2005-09-3623
209. Anderson BE, McNiff JM, Matte C, Athanasiadis I, Shlomchik WD, Shlomchik MJ (2004) Recipient CD4+ T cells that survive irradiation regulate chronic graft-versus-host disease. Blood 104:1565-1573. doi:10.1182/blood-2004-01-0328

210. Zhang Y, Hexner E, Frank D, Emerson SG (2007) CD4+ T cells generated de novo from donor hemopoietic stem cells mediate the evolution from acute to chronic graft-versus-host disease. J Immunol 179:3305-3314

211. Chen X (2007) Absence of regulatory T-cell control of TH1 and TH17 cells is responsible for the autoimmune-mediated pathology in chronic graft-versus-host disease. Blood 110:3804-3813. doi:10.1182/blood-2007-05-091074

212. Goldberg G (2007) Clinical strategies to enhance $T$ cell reconstitution. Semin Immunol 19:289-296. doi:10.1016/j. smim.2007.08.001

213. Finch PW, Rubin JS (2004) Keratinocyte growth factor/fibroblast growth factor 7, a homeostatic factor with therapeutic potential for epithelial protection and repair. Adv Cancer Res :69-115. doi:10.1016/S0065-230X(04)91003-2

214. Radtke ML, Kolesar JM (2005) Palifermin (Kepivance) for the treatment of oral mucositis in patients with hematologic malignancies requiring hematopoietic stem cell support. J Oncol Pharm Pract 11:121-125. doi:10.1191/1078155205jp159oa

215. Siddiqui MA, Wellington K (2005) Palifermin: in myelotoxic therapy-induced oral mucositis. Drugs 65:2139-2146. doi:10.2165/00003495-200565150-00008

216. Guo L, Degenstein L, Fuchs E (1996) Keratinocyte growth factor is required for hair development but not for wound healing. Genes Dev 10:165-175. doi:10.1101/gad.10.2.165

217. Min D, Panoskaltsis-Mortari A, Kuro OM, Hollander GA, Blazar BR, Weinberg KI (2007) Sustained thymopoiesis and improvement in functional immunity induced by exogenous KGF administration in murine models of aging. Blood 109:2529 2537. doi:10.1182/blood-2006-08-043794

218. Min D, Taylor PA, Panoskaltsis-Mortari A, Chung B, Danilenko DM, Farrell C, Lacey DL, Blazar BR, Weinberg KI (2002) Protection from thymic epithelial cell injury by keratinocyte growth factor: a new approach to improve thymic and peripheral T-cell reconstitution after bone marrow transplantation. Blood 99:4592-4600. doi:10.1182/blood.V99.12.4592

219. Seggewiss R, Loré K, Guenaga FJ, Pittaluga S, Mattapallil J, Chow CK, Koup RA, Camphausen K, Nason MC, MeierSchellersheim M, Donahue RE, Blazar BR, Dunbar CE, Douek DC (2007) Keratinocyte growth factor augments immune reconstitution after autologous hematopoietic progenitor cell transplantation in rhesus macaques. Blood 110:441-449. doi:10.1182/blood-2006-12-065623

220. Blazar BR, Weisdorf DJ, DeFor TE, Goldman A, Braun T, Silver S, Ferrara JLM (2006) Phase $1 / 2$ randomized, placebo-control trial of palifermin to prevent graft-versus-host disease (GVHD) after allogeneic hematopoietic stem cell transplantation (HSCT). Blood 108:3216-3222. doi:10.1182/blood-2006-04-017780

221. Seggewiss R, Einsele H (2007) Hematopoietic growth factors including keratinocyte growth factor in allogeneic and autologous stem cell transplantation. Semin Hematol 44:203-211. doi:10.1053/j.seminhematol.2007.04.009

222. Kelly RM, Highfill SL, Panoskaltsis-Mortari A, Taylor PA, Boyd RL, Holländer GA, Blazar BR (2008) Keratinocyte growth factor and androgen blockade work in concert to protect against conditioning regimen-induced thymic epithelial damage and enhance T-cell reconstitution after murine bone marrow transplantation. Blood 111:5734-5744. doi:10.1182/blood-2008-01-136531

223. Heng TS, Goldberg GL, Gray DH, Sutherland JS, Chidgey AP, Boyd RL (2005) Effects of castration on thymocyte development in two different models of thymic involution. J Immunol $175: 2982-2993$ 
224. Sutherland JS, Goldberg GL, Hammett MV, Uldrich AP, Berzins SP, Heng TS, Blazar BR, Millar JL, Malin MA, Chidgey AP, Boyd RL (2005) Activation of thymic regeneration in mice and humans following androgen blockade. J Immunol 175:2741-2753

225. Olsen NJ, Olson G, Viselli SM, Gu X, Kovacs WJ (2001) Androgen receptors in thymic epithelium modulate thymus size and thymocyte development. Endocrinology 142:1278-1283. doi:10.1210/en.142.3.1278

226. Erickson M, Morkowski S, Lehar S, Gillard G, Beers C, Dooley J, Rubin JS, Rudensky A, Farr AG (2002) Regulation of thymic epithelium by keratinocyte growth factor. Blood 100:3269-278. doi:10.1182/blood-2002-04-1036
227. Suniara RK, Jenkinson EJ, Owen JJ (2000) An essential role for thymic mesenchyme in early $\mathrm{T}$ cell development. J Exp Med 191:1051-1056. doi:10.1084/jem.191.6.1051

228. Revest JM, Spencer-Dene B, Kerr K, De Moerlooze L, Rosewell I, Dickson C (2001) Fibroblast growth factor receptor 2-IIIb acts upstream of Shh and Fgf4 and is required for limb bud maintenance but not for the induction of Fgf8, Fgf10, Msx1, or Bmp4. Dev Biol 231:47-62. doi:10.1006/dbio.2000.0144

229. Brauchle M, Fässler R, Werner S (1995) Suppression of keratinocyte growth factor expression by glucocorticoids in vitro and during wound healing. J Invest Dermatol 105:579-584. doi:10.1111/1523-1747.ep12323521 